\title{
Synthesis and Biological Aspects of Mycolic Acids: An Important Target Against Mycobacterium tuberculosis
}

\author{
Marcus Vinícius Nora de Souza ${ }^{1, \star}$, Marcelle de Lima Ferreira ${ }^{1,2}$, \\ Alessandra Campbell Pinheiro ${ }^{1,3}$, Maurício Frota Saraiva ${ }^{4}$, \\ Mauro Vieira de Almeida ${ }^{4}$, and Marcelo Siqueira Valle ${ }^{4}$ \\ ${ }^{1}$ Instituto de Tecnologia em Fármacos-Far-Manguinhos, Rua Sizenando Nabuco, \\ 100, Manguinhos, 21041-250 Rio de Janeiro, RJ - Brazil; ${ }^{2}$ Instituto de Química, \\ Universidade Federal Fluminense, Campus do Valonguinho s/n Centro 24020-150 \\ Niterói, RJ - Brazil; ${ }^{3}$ Instituto de Química, Universidade Federal do Rio de Janeiro, \\ 21941-590 Rio de Janeiro, RJ - Brazil; ${ }^{4}$ Departamento de Química, Universidade \\ Federal de Juiz de Fora, 36036-330 Juiz de Fora, MG - Brazil
}

E-mail: marcos souza@far.fiocruz.br; marcellelf@gmail.com; apinheiro@far.fiocruz.br; mfrotas@bol.com.br; mauro.almeida@ufjf.edu.br; marcelovalle@gmail.com

Received April 4, 2008; Accepted July 10, 2008; Published July 31, 2008

Mycolic acids are an important class of compounds, basically found in the cell walls of a group of bacteria known as mycolata taxon, exemplified by the most famous bacteria of this group, the Mycobacterium tuberculosis (M. tb.), the agent responsible for the disease known as tuberculosis (TB). Mycolic acids are important for the survival of $M$. $t b$. For example, they are able to help fight against hydrophobic drugs and dehydration, and also allow this bacterium to be more effective in the host's immune system by growing inside macrophages. Due to the importance of the mycolic acids for maintenance of the integrity of the mycobacterial cell wall, these compounds become attractive cellular targets for the development of novel drugs against TB. In this context, the aim of this article is to highlight the importance of mycolic acids in drug discovery.

KEYWORDS: tuberculosis, mycolic acid, drug discovery

\section{INTRODUCTION}

The mycobacterial cell wall is very important as a cellular component surrounding the cell membrane, providing additional support and protection. Basically, it is comprised of three covalently linked substructures: mycolic acids, peptidoglycan, and arabinogalactan, which represent over $60 \%$ of cell dry weight[1]. Mycolic acids are an important class of compounds, basically found in the cell walls of a group of bacteria known as mycolata taxon, exemplified by the most famous bacteria of this group, the Mycobacterium tuberculosis $(M . t b .)^{* *}$, the agent responsible for the disease known as tuberculosis (TB)[2]. Mycolic acids are important for the survival of $M$. $t b$. For example, they are able to help fight against hydrophobic drugs and dehydration, and also allow this bacterium to be more effective in the

${ }^{* *}$ Abbreviations used in text also appear at the end of the article. 
host's immune system by growing inside macrophages[3]. Structurally, mycolic acids are comprised of long fatty acids containing different functional groups, such as double bonds, keto, ester, epoxy, methoxy, and cyclopropane ring. They possess a broad family of over 500 species, which are commonly characterized by the numbers of carbon atoms presented in the fatty acids[1,4]. For example, mycolic acids, which possess 60-90 carbon atoms, are commonly isolated from Mycobacterium and they are called mycolic or eumycolic acids. In the case of the mycolic acids containing carbon atoms between 2260 units, they are isolated from other species, such as Nocardia and Corynobacterium, and they are named nocardomycolic and corynomycolic acids, which contain 44-60 and 22-36 carbon atoms, respectively[1,4]. Fig. 1 shows some compounds of the mycolic acid class; for example, compound $\mathbf{1}$, which is a key structural component of the cell envelope of $M . t b$., and other compounds present in different mycobacterial cell walls, such as $\alpha$-methyl-trans-cyclopropanes ( $\alpha$-mycolic acids) 2 , $\alpha$-methyl- $\beta$ methoxy groups (methoxymycolates) 3, $\alpha$-methyl- $\beta$-keto groups (ketomycolates) 4 , and $\alpha$-methyl-transepoxy groups $\mathbf{5}$.
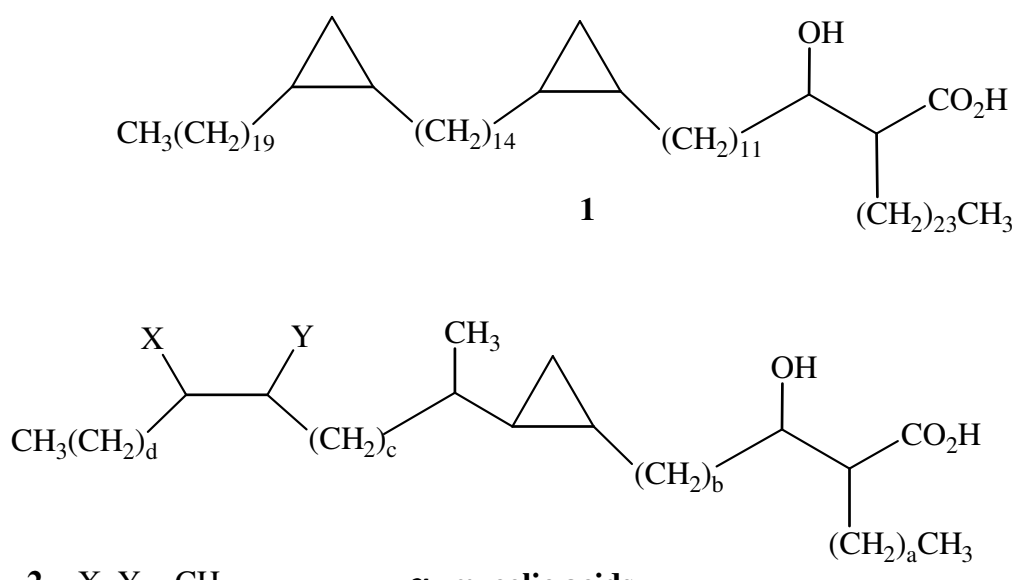

$$
\begin{array}{ll}
\mathbf{2}-\mathrm{X}, \mathrm{Y}=\mathrm{CH}_{2} & \boldsymbol{\alpha} \text {-mycolic acids } \\
\mathbf{3}-\mathrm{X}=\mathrm{CH}_{3}, \mathrm{Y}=\mathrm{OCH}_{3} & \text { methoxymycolates }
\end{array}
$$<smiles>CCCCCCC(C)C(=O)CCC(C)C(CC)C(=O)O</smiles><smiles>CCCC(C)C1OC1CCCCCCCCCCCC(O)C(CC)C(=O)O</smiles>

FIGURE 1. Some compounds of the mycolic acid class.

Mycolic acids were isolated for the first time in 1938 by Andersen and coworkers at the Chemistry Department of Yale University, from an extract of human $M$. tb., which after heating under reduced 
pressure and high temperatures, furnished the oil hexacosanoic acid in $24 \%$ yield[5]. However, despite the importance of this work, the mycolic acid structure was only elucidated 12 years later by Asselineau, which demonstrated that mycolic acids were comprised of a $\beta$-hydroxy- $\alpha$-alkyl branched chain[6]. The structure of $\alpha$-mycolic acids is divided into two parts: the mycolic motif, comprised of the $\beta$-hydroxy- $\alpha$ alkyl branched chain, and the long alkyl chain named meromycolate moiety 6 (for alkyl groups, which possess 50 or more carbon atoms). The cleavage by thermolysis applied by Andersen and coworkers in 1938[5] of hydroxyacid functionality, producing the meromycolaldehyde 7 (Scheme 1), is still a standard procedure for the characterization of mycolic acids.
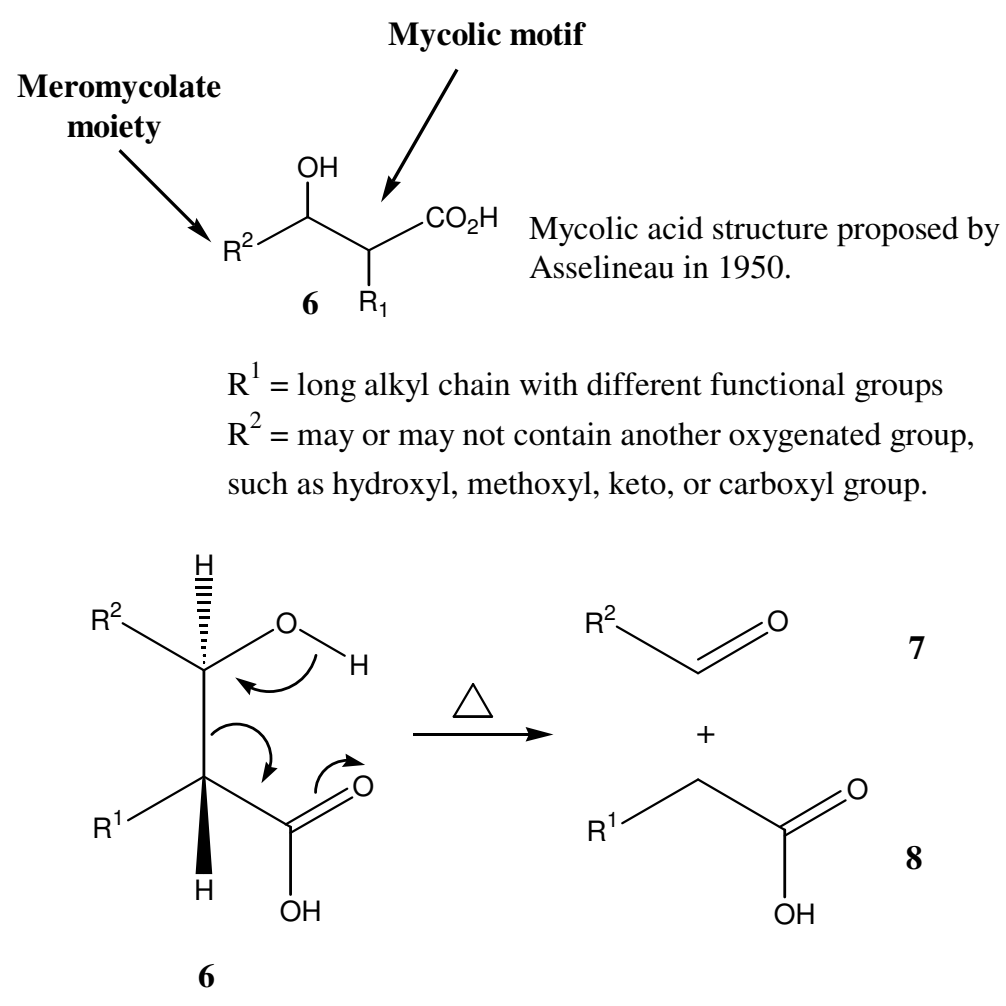

SCHEME 1. The structure of $\alpha$-mycolic acids and the cleavage by thermolysis of hydroxyacid functionality, producing the meromycolaldehyde 7.

During the period of 1950-1960, with the development of chromatography techniques, a variety of mycolic acid structures were identified in different mycobacteria strains. However, a more precise structural definition of the different species of mycolic acids started during the period of 1960-1970, with the use of NMR and MS analyses. During the period of 1970-1980, little scientific progress was made in the mycolic acid field, perhaps due to the fact that TB was almost eradicated. However, after 1980, TB again became a worldwide problem due to the AIDS epidemic, the advent of multidrug resistant (MDR) strains, and the lack of new drugs in the market[7]. In this context, the mycobacterial cell wall regained attention, and today there is a better comprehension of different aspects of the cell wall of $M$. $t b$., such as structure, biosynthesis, and genetics[2], due to modern analysis techniques and the elucidation of the $M$. $t b$. Genome.

Due to the importance of the mycolic acids for maintenance of the integrity of the mycobacterial cell wall, these compounds become attractive cellular targets for the development of novel drugs against TB because the drugs would be capable of acting on proteins or enzymes encoded for specific genes of $M$. $t b$. In this context, the aim of this article is to highlight the importance of mycolic acids in drug discovery. 


\section{BIOSYNTHESIS OF MYCOLIC ACIDS}

The knowledge concerning the biosynthesis of mycolic acids is very important, both for the discovery of new therapeutic targets against TB and for the briefing of the mechanisms of action of the drugs currently used[8]. In this context, in general, biosynthesis of fatty acids is produced through some cycles of reactions, as condensations, dehydratations, keto reductions, and enoyl reductions. In this process, an enzyme series, such as $\beta$-ketoacyl synthase (KAS), $\beta$-ketoacyl reductase (KR), $\beta$-hydroxyacyl dehydrase (DE), and enoyl reductase (ER), is involved. More specifically, there are two types of fatty acid synthase systems (FAS): the multifunctional polypeptide FAS I system, which promotes the synthesis de novo of fatty acids, generating precursors of 14-26 carbon atoms; and the FAS II system, which includes monofunctional enzymes, which elongate the products of FAS I to give rise to precursors of mycolic acids of long chain[2,9].

Scheme 2 shows the main steps of the FAS I system, in which it can be evidenced that an acetyl group is elongated by two carbon units, using acetyl-CoA and malonyl-CoA as substrates to yield butyryl-S-Enz. This cycle is repeated, generating derivatives with 16 and 18 carbon atoms, used for the synthesis of membrane phospholipids; others with 20 carbons (start point where the FAS II systems take over for the synthesis of the very-long-chain mero segment of $\alpha$-, methoxy-, and keto-mycolic acids) and 26 carbons, which becomes the short $\alpha$-alkyl chain and methyl carboxyl segment of all mycolic acids of M. $t b$.[10].

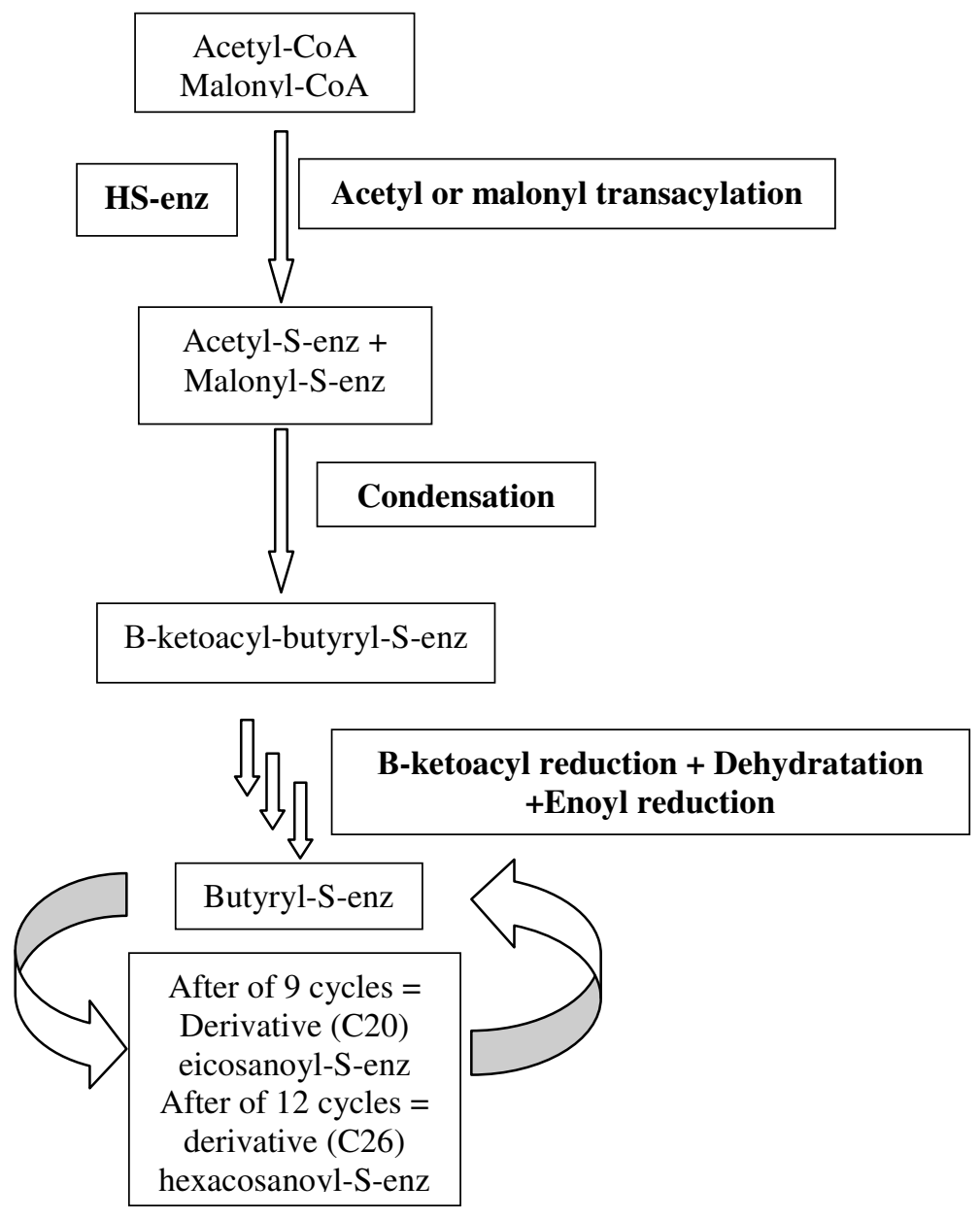

SCHEME 2. Steps of FAS I system that generates the derivatives eicosanoyl-S-enz and hexacosanoyl-S-enz. These fatty acids are released as the CoA derivatives and they will be used as precursors in FAS II. 
After the synthesis of precursors, FAS II is started (Scheme 3). This system is formed of dissociable enzyme components, which act on a substrate bound to an ACP (acyl carrier protein). The first step consists of a reaction that aims to convert the produced precursors $\mathbf{1 1}$ and $\mathbf{1 2}$ in FAS I to $\beta$-ketoacyl derivatives 13 through an enzyme called $\beta$-ketoacyl-ACP-synthase (encoded by KasA/KasB gene)[11]. This reaction uses as cosubstrate a molecule of malonyl-S-ACP 10, which is derived from the reaction between malonyl-S-CoA 9 and the enzyme malonyl-CoA ACP transacylase, which is encoded by FabD gene[12,13]. The second step involves the reduction of the product $\mathbf{1 3}$ obtained in the last step by enzyme $\beta$-ketoacyl-ACP-reductase, which furnished the intermediate 14. This product is then converted to unsaturated derivative 15 by $\beta$-hydroxyacyl-ACP-dehydratase. Compound 15 is reduced by 2 -transenoyl-ACP reductase (encoded by InhA gene) to yield the final product 16, which is two carbons longer than the starting substrate $\mathbf{1 1}$ and 12, which can be further recycled to produce others derivatives with chains increased by two carbon atoms[14,15].

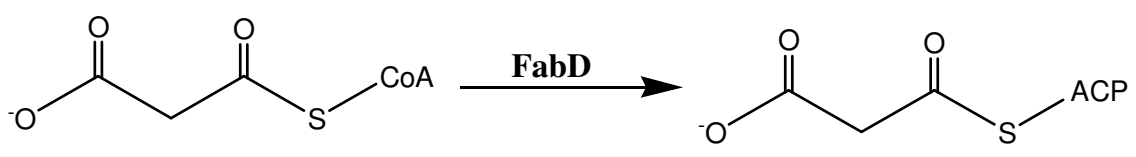

Malonyl-S-CoA

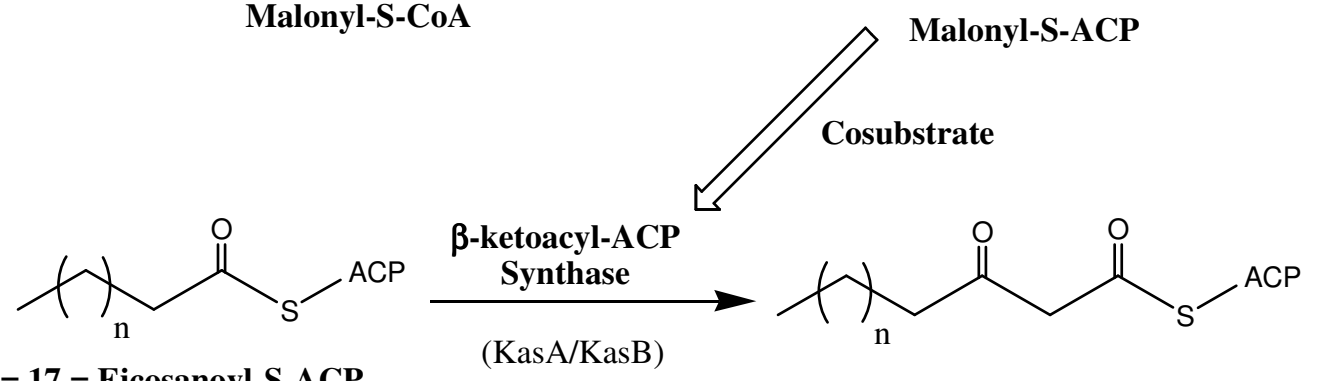

$$
\mathrm{n}=17 \text { = Eicosanoyl-S-ACP }
$$

$$
\mathrm{n}=\mathbf{2 3}=\text { Hexacosanoyl-S-ACP }
$$

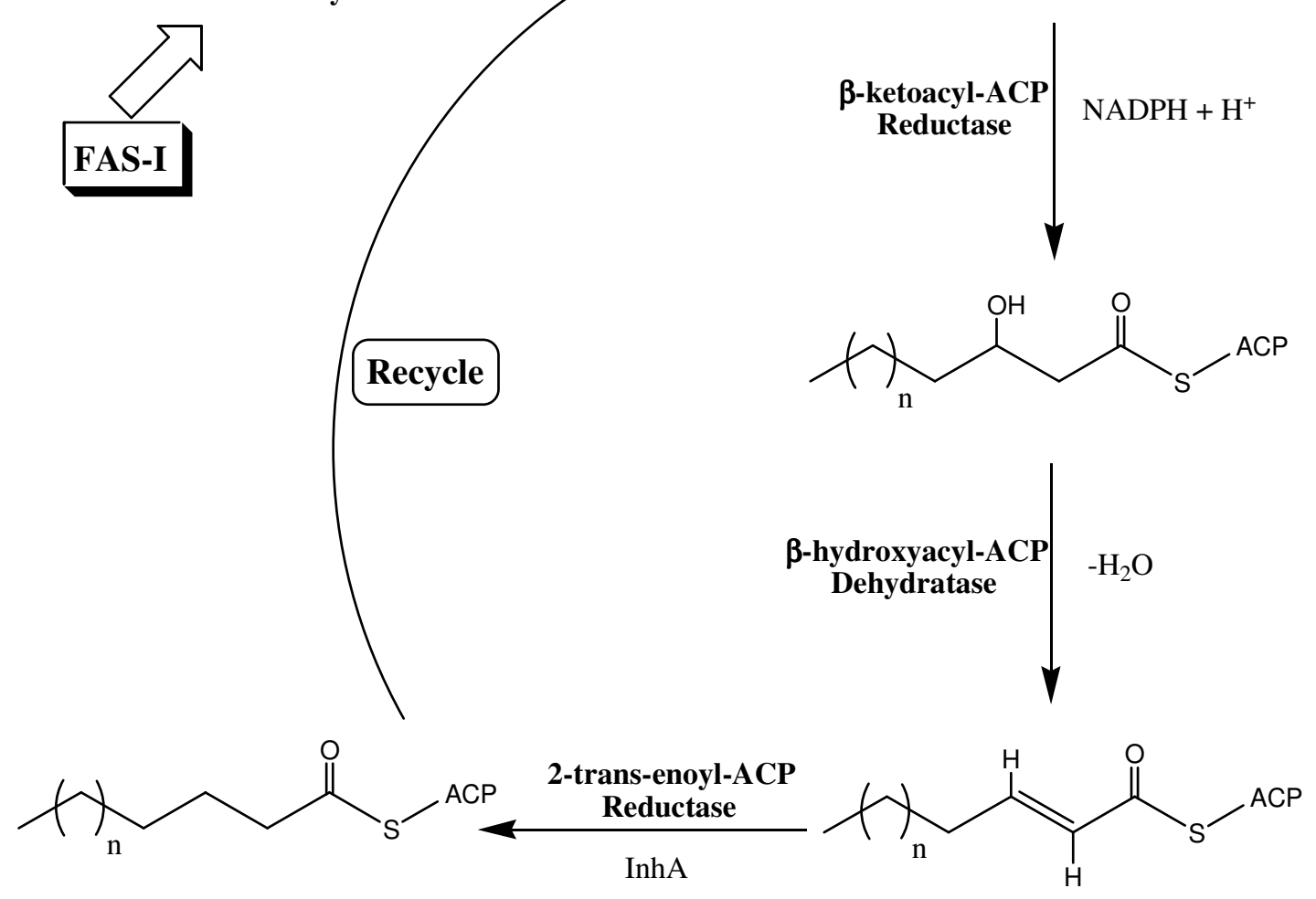

SCHEME 3. Elongation of fatty acids by FAS II, which produces long-chain mycolic acid derivatives. 
Subsequently, the introduction of functional groups into the mero chain is realized through desaturation of saturated alkyl chain $\mathbf{1 7}$ to yield two cis double bonds $\mathbf{1 8}$, which are converted easily to others groups as necessary. This reaction occurs through the action of an aerobic terminal, mixed function enzyme called desaturase, which promotes the oxidation of saturated $\mathbf{1 7}$ to yield unsaturated fatty acid $\mathbf{1 8}$ with the coincident reduction of molecular oxygen and oxidation of NADPH.

Others derivatives can be synthesized from the unsaturated fatty acid $\mathbf{1 8}$ formed in the desaturation reaction, e.g., containing methoxy and keto moieties, the methyl branches adjacent to trans-olefins and the bridging methylenes of the cyclopropane rings. These derivatives are all derived from methionine, via S-adenosyl-L-methionine (SAM) 19, which adds a methyl group to the unsaturated derivative, originating a carbonium ion 20, which is the key intermediate for the others transformations[2,16] (Scheme 4).

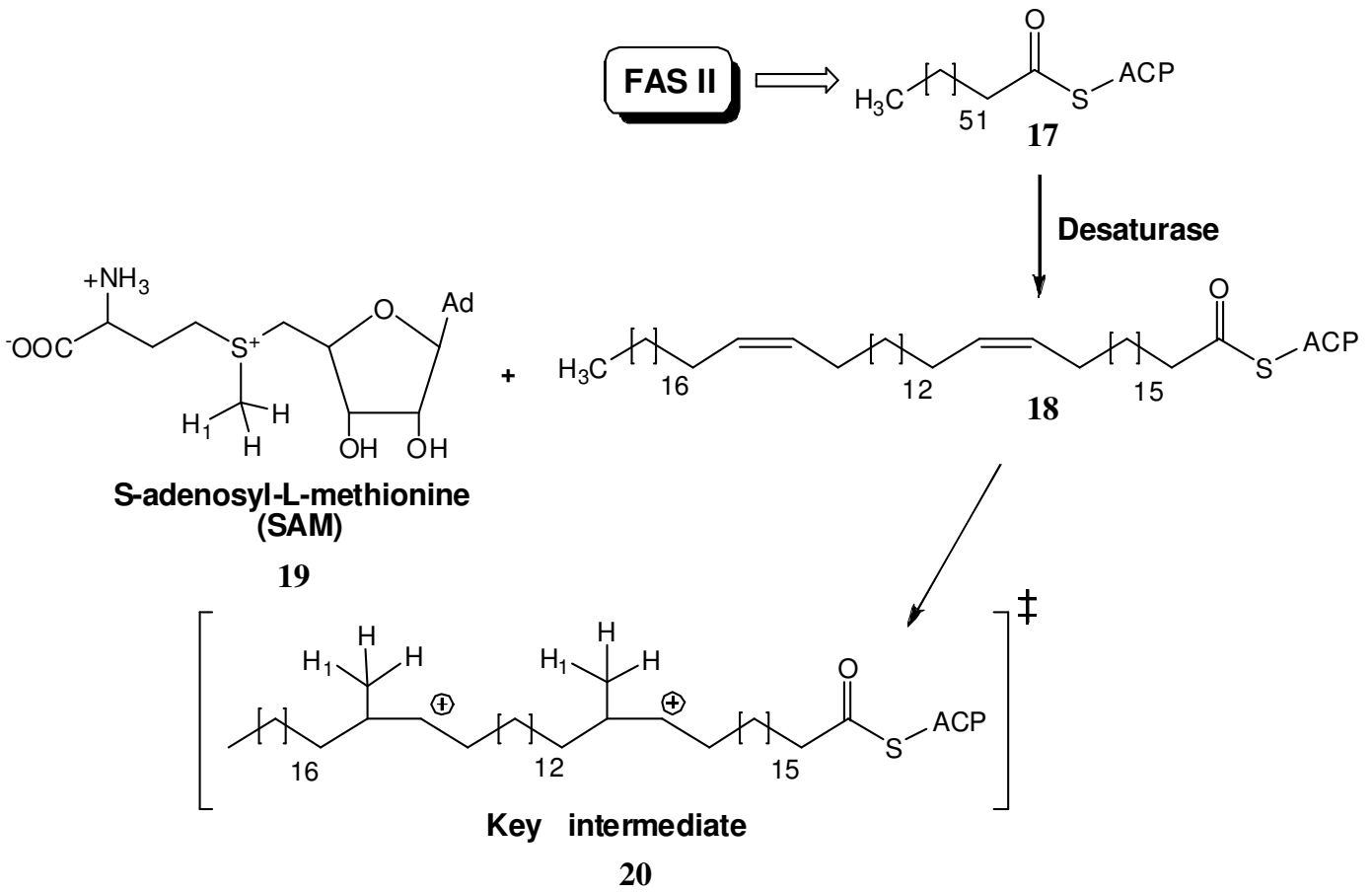

SCHEME 4. Formation of key intermediate (carbonium ion) that will be converted into other functionalized derivatives.

After the formation of the intermediate 20, other SAM-dependent methyl transferase enzymes act to yield other desired derivatives (Table 1 and Scheme 5). Table 1 shows the genes and the corresponding proteins responsible for the preparation of derivatives 21-25[17,18,19,20,21].

After these modifications, the $\beta$-hydroxy acid moiety is introduced through a biological equivalent mechanism to a Claisen-Condensation (Scheme 6). This process starts with the conversion of the derivatives 12 and 22 generated from the FAS I and FAS II processes, respectively. Thus, the hexacosanoyl derivative $\left(\mathrm{C}_{26}-\mathrm{S}-\mathrm{CoA}\right) \mathbf{1 2}$ is converted to the 2-carboxyl- $\mathrm{C}_{26}-\mathrm{CoA} \mathbf{2 6}$ by acyl-CoA carboxylases $\left(\mathrm{AccD}_{4}\right.$ and $\left.\mathrm{AccD}_{5}\right)$. The $\alpha$-meroacyl-S-ACP 22 derivative is transformed to $\alpha$-meroacylAMP 27 by the enzyme called FadD32. These two formed products are the substrates for the condensation reaction catalyzed by the complex enzyme Pks13 (polyketide synthase 13). This enzyme has five domains: PPB (two nonequivalent domains), KS, AT, and TE. First, the $\alpha$-meroacyl-S-ACP 22 and 2-carboxyl- $\mathrm{C}_{26}$-CoA 26 are covalently attached to each one of the PPB domains, which are separate for the AT and KS domains. After that, the meroacyl group is transferred to the KS domain, where the condensation reaction occurs. This step is followed by the reduction of the 3-oxo group to the secondary alcohol by an unknown reductase to yield the mature $\alpha$-mycolate[22]. 
TABLE 1

Responsible Genes and Proteins for Modifications in the Mero Chain, after the Desaturation Reaction

\begin{tabular}{|c|c|c|}
\hline Genes & Proteins & Functions \\
\hline cma1 & CMAS-1 & Introduces a cyclopropane ring at the distal position. \\
\hline cma2 & CMAS-2 & $\begin{array}{l}\text { Introduces a cyclopropane ring at the proximal position. It has specificity for cis double } \\
\text { bonds. }\end{array}$ \\
\hline mma4 & MMAS-4 & Introduces the hydroxyl group with an adjacent methyl branch at the distal position. \\
\hline mma3 & MMAS-3 & Converts the hydroxyl group to form a methyl ether. \\
\hline mma2 & MMAS-2 & $\begin{array}{l}\text { It is similar to CMAS-2, but MMAS- } 2 \text { introduces a cyclopropane ring in oxygenated series } \\
\text { of mycolates while CMAS- } 2 \text { acts in the } \alpha \text {-series. }\end{array}$ \\
\hline mma1 & MMAS-1 & Converts the proximal cis double to a trans double bonds with an allylic methyl branch. \\
\hline
\end{tabular}

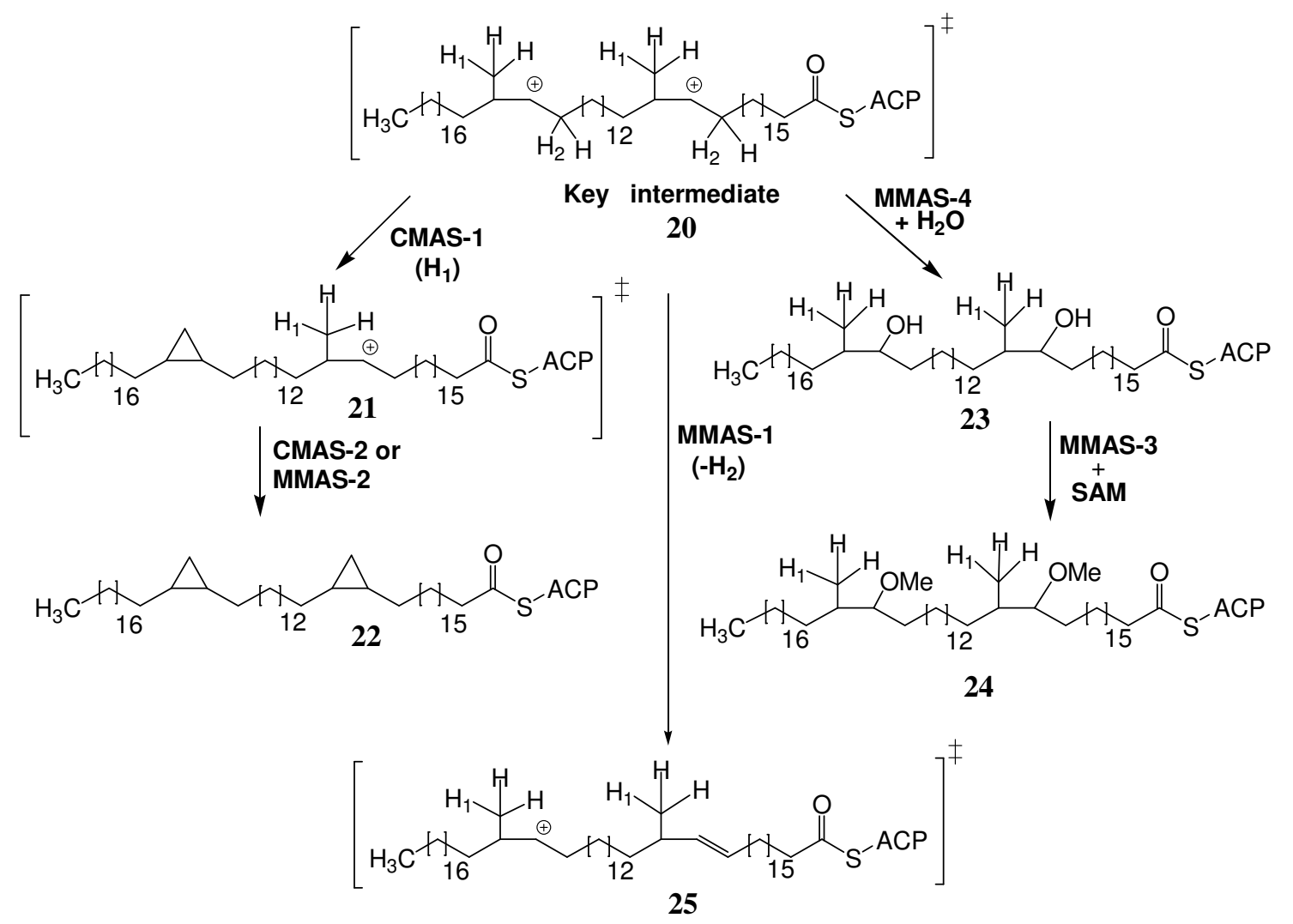

SCHEME 5. Preparation of important derivatives 21-25 by SAM-dependent methyl transferase enzymes.

At the end of the synthesis, transport of newly synthesized mycolic acids followed by attachment to the peptidoglycan-arabinogalactan complex and the formation of TDM (trehalose dimycolate) $\mathbf{3 3}$ are produced. This step is not well known, only the mycolyltransferase function of antigen 85 (Ag85) is well established. Therefore, many researchers have been studying this pathway. Takayama and coworkers suggested a completely new pathway to the synthesis of TMM 32, which is described in Scheme $7[10,23,24,25]$. In this scheme, the final product of the synthesis of the mycolic acids is found to be attached to Pks 13. The mycolyl group is transferred to D-mannopyranosyl-1-phosphoheptaprenol 28 to 

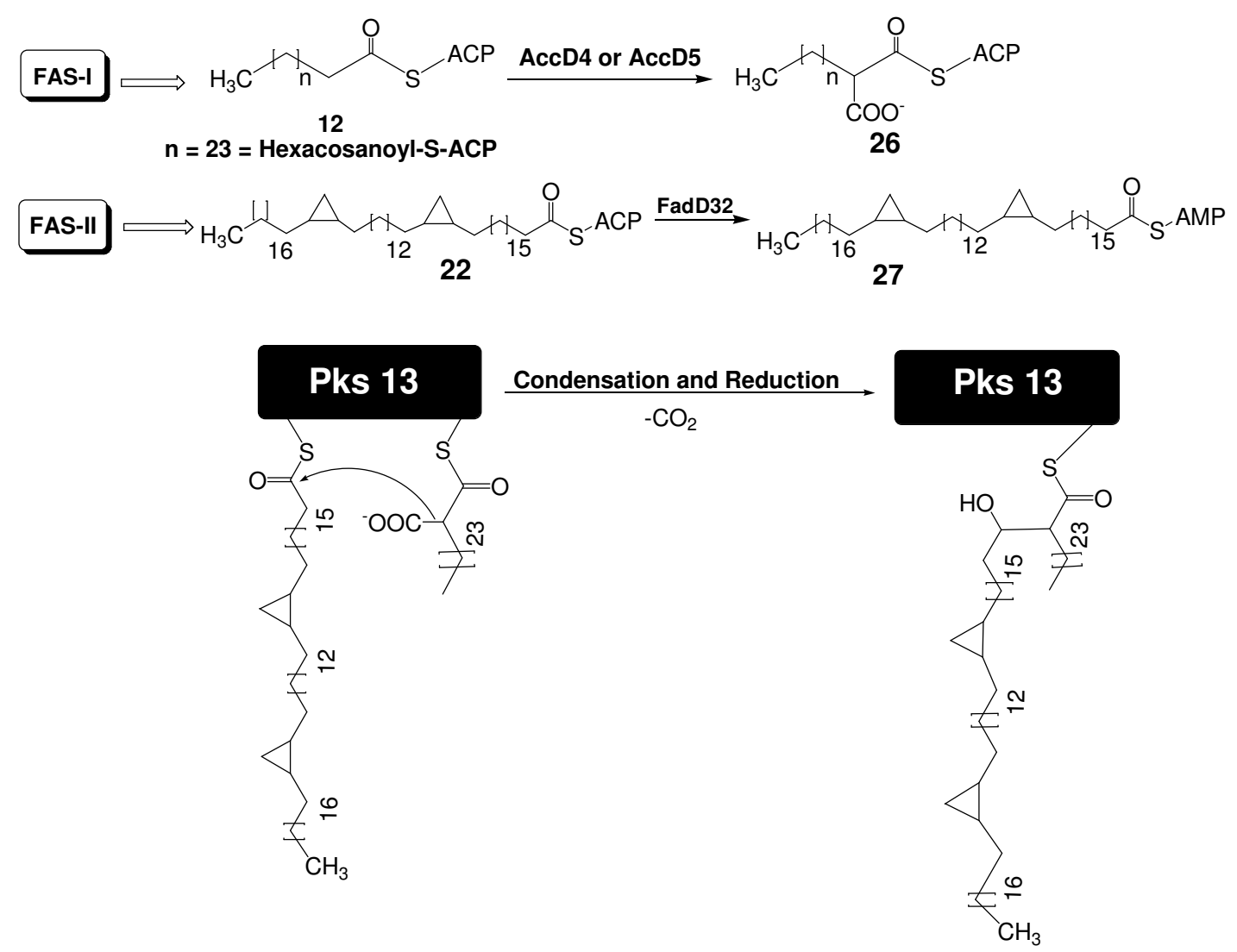

SCHEME 6. Synthesis of $\alpha$-mycolic acid by Pks 13 is shown in a simplified way. First, the products $\mathbf{1 2}$ and $\mathbf{2 2}$ derived from FAS I and FAS II, respectively, are converted to 2-carboxyl- $\mathrm{C}_{26}-\mathrm{CoA} 26$ and $\alpha$-meroacyl-AMP 27, respectively. Further, these derivatives are covalently attached to $\mathrm{Pks} 13$, which is processed via the condensation reaction, followed by a reduction of the 3-oxo group to the secondary alcohol.

yield Myc-PL (6-O-mycolyl- $\beta$-D-mannopyranosyl-1-phosphoheptaprenol) 29. This reaction is catalyzed by a proposed cytoplasmatic mycolyl transferase I, followed by the Myc-PL, which migrates to the surface of the cell membrane and interacts with the $\mathrm{ABC}$ transporter, where the three last reactions are processed. In the first step, the mycolyl group is transferred to trehalose-6-phosphate $\mathbf{3 0}$ by mycolyl transferase II to yield 6-O-mycolyl-treh-6'-P 31. In the second step, the dephosphorylation is promoted by TMM-P-phosphatase to form TMM 32. Finally, in the last step, substance $\mathbf{3 2}$ is transferred outside the cell through the ABC transporter, where it is involved in the synthesis of both TDM 33 and cell wall arabinogalactan-mycolate (AG-M). These processes are mediated by Ag 85 complex.

\section{PEPTIDOGLYCAN AND ARABINOGALACTAN}

Peptidoglycan and arabinogalactan are also important polysaccharides in the mycobacterial cell walls, which are linked by covalent attachment to arabinogalactan (AG), a polymer composed primarily of Darabinofuranosyl and D-galactofuranosyl residues, attached to mycolic acids and peptidoglycan and is known as mycolyl-arabinogalactan-peptidoglycan (mAGP) complex (Scheme 8)[26]. The biosynthesis of this complex involves different enzymes, such as galactopyranosyl mutase and epimerases, and arabinosyl and galactofuranosyl transferases. 


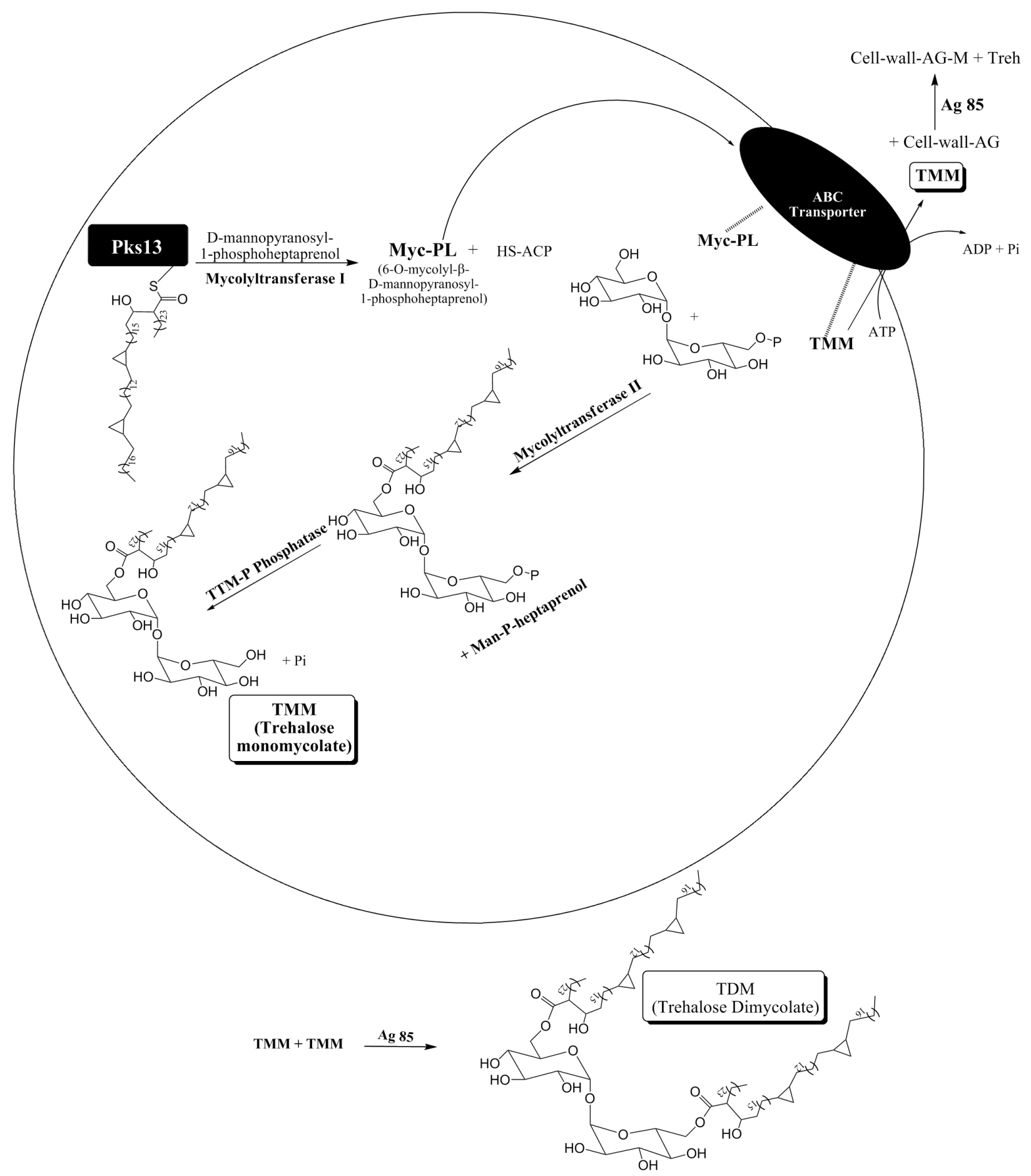

SCHEME 7. Transport of newly synthesized mycolic acids followed by attachment to the peptidoglycan-arabinogalactan complex and the formation of TDM 33.

The mycobacterial cell wall is also comprised of 6,6'-dimycolyltrehalose 34 (Fig. 2), biosynthesized by three homologous proteins, Ag85, A, B, and C, which possess mycolyltransferase. The antigen 85 (Ag 85) complex is a major protein component of the mycobacterial cell wall, all of which contribute to cell 
wall biosynthesis and help to maintain its integrity, catalyzing the transfer of mycolic acids into the envelope[27].

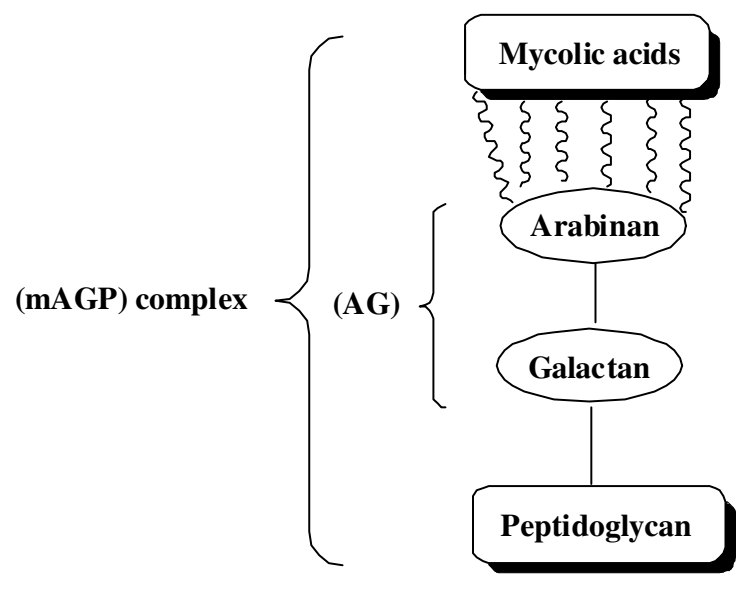

SCHEME 8. Mycolyl-arabinogalactan-peptidoglycan (mAGP) complex.

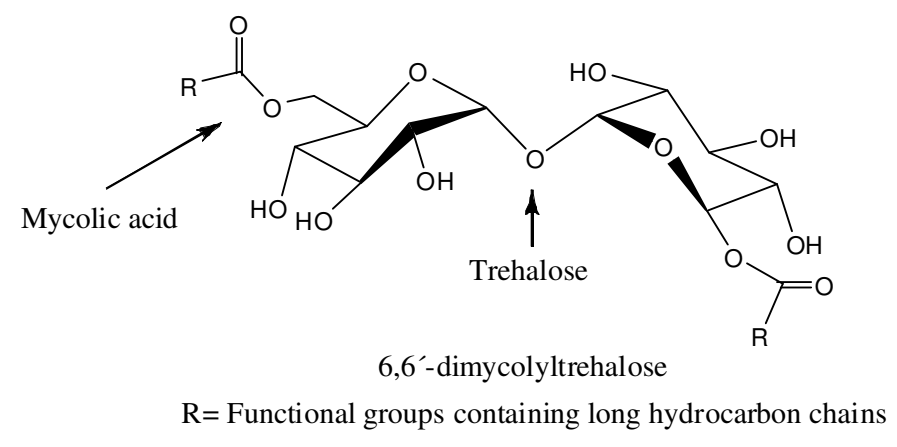

34

FIGURE 2. Structure of 6,6'-dimycolyltrehalose 34.

\section{DRUGS THAT INHIBIT THE BIOSYNTHESIS OF MYCOBACTERIUM TUBERCULOSIS'S CELL WALL}

Nowadays, there are two prodrugs that inhibit specific enzymes involved in the biosynthesis of these constituents of the cell wall: isoniazid and ethionamide (Fig. 3).
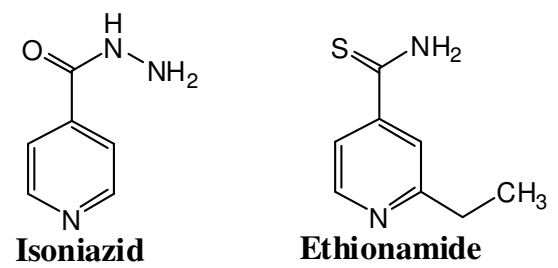

Ethionamide

FIGURE 3. Structures of isoniazid and ethionamide. 


\section{Isoniazid (INH)}

INH was synthesized, for the first time, in 1912, for the Czech researchers Meyer and Malley as part of their doctoral work in Prague. However, only 4 decades later, after investigations at pharmaceutical companies Hoffman La Roche, Farbenfabriken Bayer, and Squibb Institute for Medical Research, each independently discovered INH as an anti-TB agent. The first clinical trial began in 1951 at Sea View Hospital in Staten Island, NY and was reported to the public in 1952[28].

INH is one of the most powerful synthetic agents against the $M$. th. complex and its minimum inhibitory concentration (MIC) is very low $(0.1-0.5 \mu \mathrm{g} / \mathrm{ml})$. This high potency can be justified for the drug to possess many targets inside of the cell. However, the mode of action of this compound is still not completely understood.

The probable mechanism that is more accepted involves the inhibition of biosynthesis of mycolic acids, which compose the mycobacterial cell wall (Scheme 9)[29]. However, before that can happen, it is known that INH needs a previous in vivo activation to exercise its anti-TB activity. The responsible enzyme for this function is called $\mathrm{KatG}$, which has dual activities of catalase and peroxidase. This enzyme has two identical subunits of $80 \mathrm{kDa}$ and protects the $M$. $t b$. of the noxious lesion caused by hydrogen peroxide generated during the oxidative metabolism[30,31].

The activation of INH through this enzyme can generate isonicotinic acid, acyl radicals, peracids, and aldehydes capable of reacting with nucleophilic groups present inside the cell, e.g., the formation of the isonicotinoyl radical 37, which reacts with the nicotinamide group of NAD (nicotinamide adenine dinucleotide) to yield the INH-NAD adduct 38[32,33]. This adduct inhibits and binds to enzymes involved in the biosynthesis of mycolic acids, resulting in cell death. The main enzyme inhibited by the binding of the INH-NAD adduct is called trans-2-enoyl-ACP reductase, encoded by the InhA gene. This enzyme is an enoyl reductase that catalyzes the NADH-dependent reduction of long-chain trans-2-enoylACP, in the last step of FAS II, promoting the stop of the elongation phase of mycolic acids and cell lysis[34].

\section{Ethionamide (ETH)}

$\mathrm{ETH}$, a structural analogue of INH, is only used in case of bankruptcy of the front-line drugs. It is the most frequently used drug for the treatment of drug-resistant TB. ETH, like INH, is a prodrug, which needs a previous activation to inhibit the synthesis of mycolic acids, leading to bactericidal activity[35,36,37] (Scheme 9). The responsible enzyme for this activation is a monooxygenase called EthA. Then, the activated ETH 40 reacts with $\mathrm{NAD}^{+}$to yield an ETH-NAD $\mathbf{4 2}$ adduct that had been hypothesized to be the inhibitor of InhA[38] (Scheme 9).

\section{Ethambutol (ETM)}

Besides mycolic acids, others constituents of the mycobacterial cell wall are presented as interesting cell targets in the combat to the Koch's bacillus, e.g., the arabinogalactan (AG), an important polysaccharide that forms the mAGP complex of the cell wall (Scheme 8). ETM is one drug that is capable of promoting inhibition in the biosynthesis of this constituent (Fig. 4).

ETM was synthesized in 1960, but was not used in the treatment of TB until 1968. It is important to highlight that the $(S, S)$-ethambutol is the isomeric form used, because the $(R, R)$-ethambutol causes blindness.

The probable action mechanism of ETM involves the inhibition of the arabinofuranosyl transferases, important enzymes that promote the polymerization of arabinose into the arabinan domain of AG[39,40]. The enzyme named AftA catalyzes the addition of the first key arabinofuranosyl residue $\mathbf{4 5}$ from the sugar donor $\beta$-D-arabinofuranosyl-1-monophosphoryldecaprenol (DPA) 44 to the galactan domain of the cell 


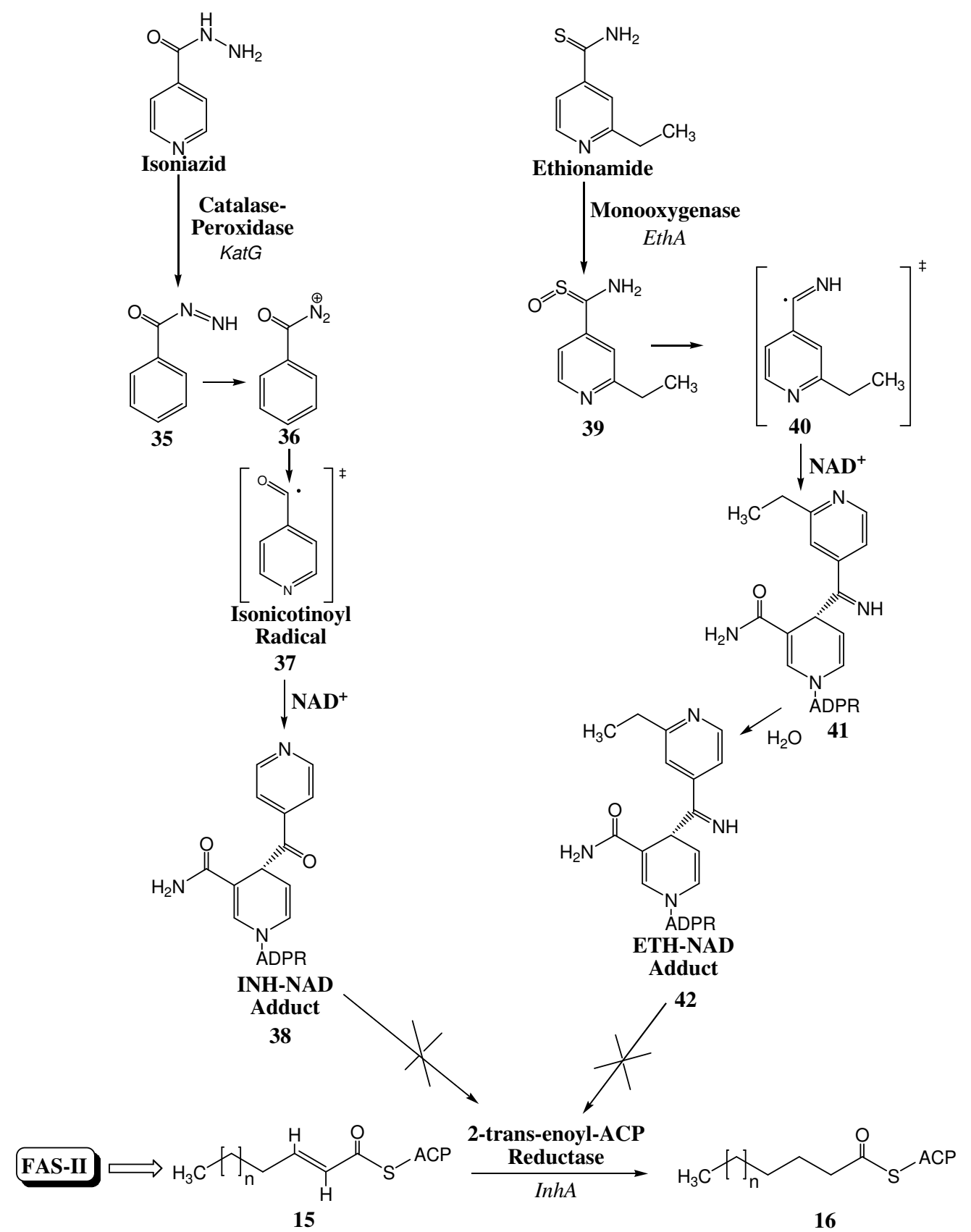

SCHEME 9. The probable action mechanism of INH and ETH, which inhibits the biosynthesis of mycolic acids.<smiles>C[C@H](CO)NCCN[C@H](C)CO</smiles>

\section{Ethambutol}

FIGURE 4. Structure of ETM. 
wall[41,42]. Subsequently, additions are promoted by other arabinofuranosyl transferases, called $E m b A$ and $E m b B$, which are inhibited by ETM. With the inhibition of AG synthesis, the formation of the mAGP complex is interrupted and may lead to increased permeability of the cell wall (Scheme 10)[43,44].

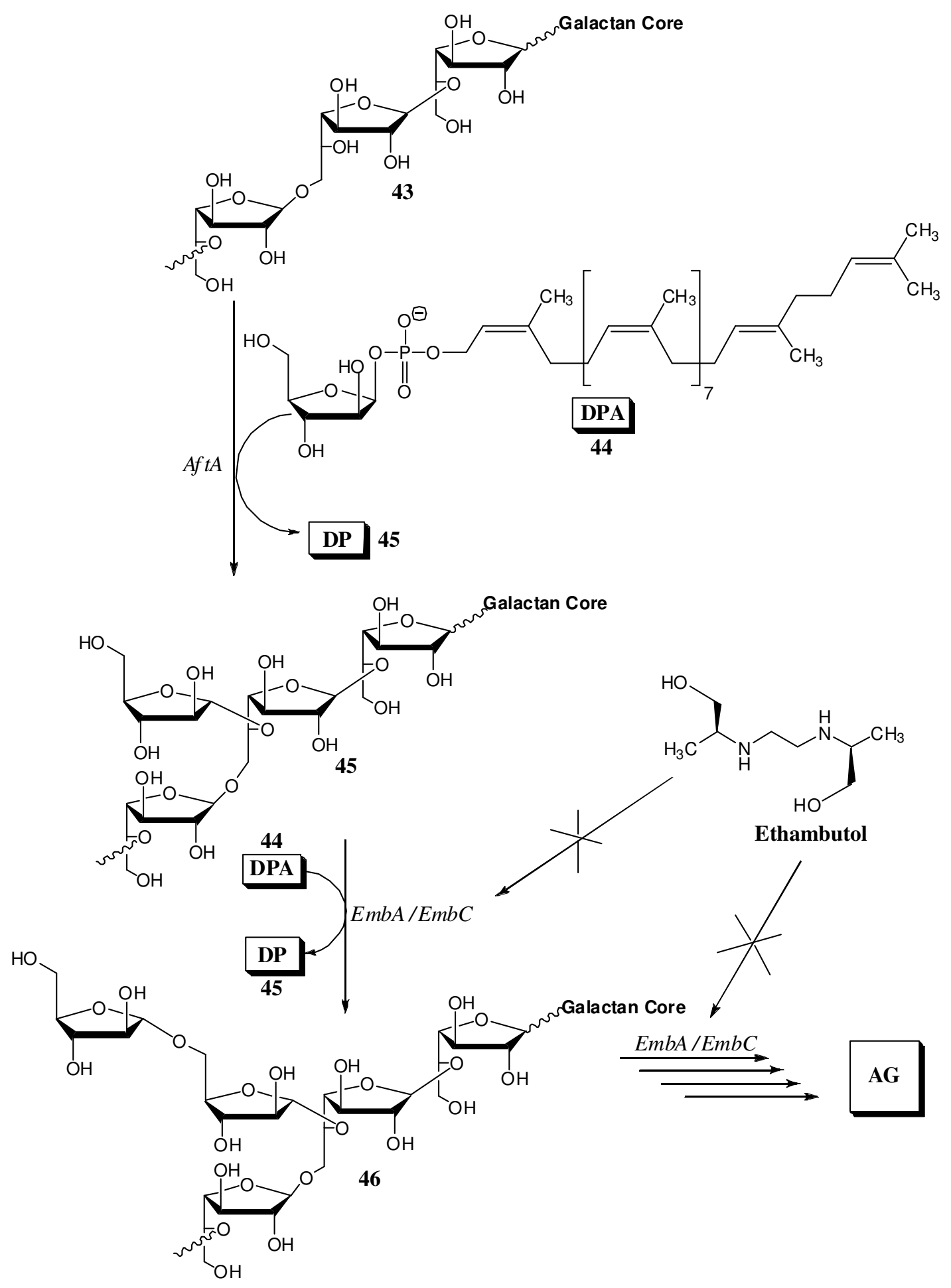

SCHEME 10. Proposed action mechanism of ETM, an inhibitor of arabinogalactan biosynthesis. 


\section{SYNTHESIS OF MYCOLIC ACIDS AND ANALOGUES}

Mycolic acids and analogues were first prepared by Minnikin and coworkers[45]. For example, mycolic acid analogues 47 (Scheme 11) were synthesized from acetonide 48, which by Witting reaction with $n$ heptyltriphenyl phosphonium bromide and n-BuLi led to the cis-alkene 49. The next step was based on the modified Simmons-Smith reaction, which allowed the synthesis of the key compound 50. After the cyclopropanation of the intermediate 49, the deprotection of the isopropylidene ring in acid condition, followed by oxidative cleavage of the diol by aqueous sodium periodate, furnished aldehyde 51. The introduction of the ester or acid chain was made in the presence of respective acid or ester phosphoranes and bases, leading to alkenes 52. After hydrogenation of the double bond and esterification, the mycolic analogues $\mathbf{4 7}$ are produced (Scheme 11).

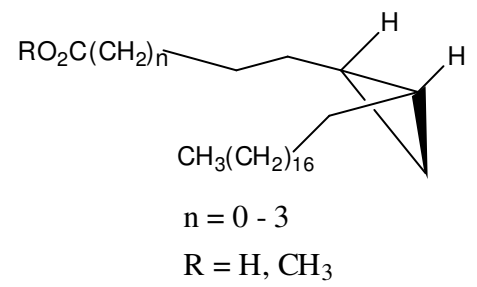

47

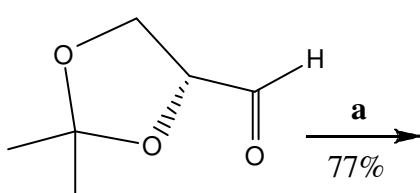

48

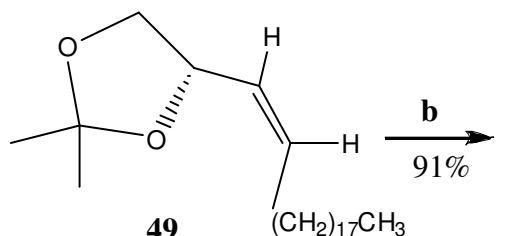

49

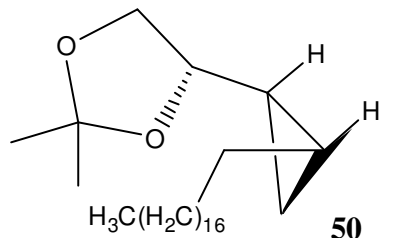

$65 \%\lfloor\mathbf{c , d}$

50

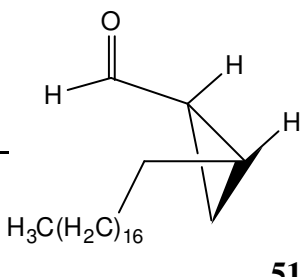

51

52

SCHEME 11. Synthesis of mycolic acid analogues 47 proposed by Minnikin and coworkers. (a) $\mathrm{Br}^{-} \mathrm{Ph}_{3} \mathrm{P}^{+}\left(\mathrm{CH}_{2}\right)_{18} \mathrm{Me}$, $n$-BuLi THF, $-78^{\circ} \mathrm{C}$; (b) $\mathrm{Et}_{2} \mathrm{Zn} \mathrm{ClCH}_{2} \mathrm{I}, 1,2$-dichloroethane $-30^{\circ} \mathrm{C}$; (c) $\mathrm{HCl}, \mathrm{MeOH}$; (d) $\mathrm{NaIO}_{4}, \mathrm{H}_{2} \mathrm{O}$; (e) (i) $\mathrm{Ph}_{3} \mathrm{P}=\mathrm{CHCO}_{2} \mathrm{Me}, \mathrm{MeOH}$; (ii) $\mathrm{Br}^{-} \mathrm{Ph}_{3} \mathrm{P}^{+}\left(\mathrm{CH}_{2}\right)_{3} \mathrm{CO}_{2} \mathrm{H}$; NaHMDS, THF, $-78^{\circ} \mathrm{C}$; (iii) $\mathrm{Br}^{-} \mathrm{Ph}_{3} \mathrm{P}^{+}\left(\mathrm{CH}_{2}\right)_{4} \mathrm{CO}_{2} \mathrm{H}, \mathrm{NaHMDS}$, THF, $-78^{\circ} \mathrm{C}$; (f) $\mathrm{N}_{2} \mathrm{H}_{4} \cdot \mathrm{H}_{2} 0, \mathrm{NaIO}_{4}, \mathrm{CuSO}_{4}, i$-PrOH. $\mathrm{CH}_{3} \mathrm{CO}_{2} \mathrm{H}, 57^{\circ} \mathrm{C}$; (g) DOWEX H ${ }^{+}, \mathrm{MeOH}$, reflux.

Another work in the mycolic acid field made by Minnikin and coworkers was a convenient synthesis of (Z)-tetracos-5-enoic acid 56 and racemic cis-4-(2-octadecylcyclopropane-1-yl)-butanoic acid 57 (Scheme 12)[46]. These acids are important in the study of biosynthetic pathways of mycolic acids, which suggests that the $\Delta^{5}$-desaturation of $\mathbf{5 6}$ is a key initial step. For example, studies made by Minnikin and coworkers showed that mycolic acid synthesis in extracts of $M$. smegmatis was stimulated by the acid 56, however strongly inhibited by the cyclopropanation to the ester $\mathbf{5 7}$. The synthesis of $\mathbf{5 7}$ was efficiently accomplished based on 1-eicosene $\mathbf{5 3}$ as starting material, which after epoxidation by $m$ chloroperoxybenzoic acid and cleavage in presence of ortho-periodic acid furnished the aldehyde $\mathbf{5 4}$ in 

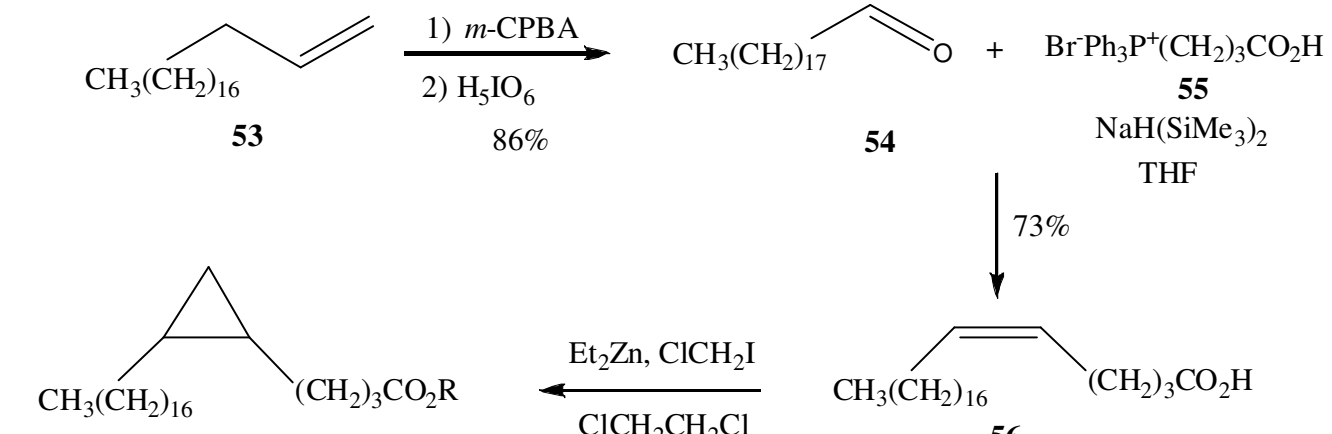

54

THF

$73 \%$

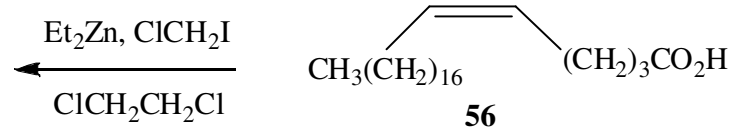

57- $\mathrm{R}=\mathrm{H}, \quad 21 \%$

$58-\mathrm{R}=\mathrm{CH}_{3}, 67 \%$

SCHEME 12. Synthesis of (Z)-tetracos-5-enoic acid 56 and racemic cis-4-(2-octadecylcyclopropane-1-yl)-butanoic acid $\mathbf{5 7}$ proposed by Minnikin and coworkers.

$86 \%$ yield (two steps). This aldehyde was coupled by Wittig reaction with the phosphonium salt 4carboxybutyltriphenylphosphonium $\mathbf{5 5}$ leading to the desired (Z)-tetracos-5-enoic acid $\mathbf{5 6}$ in $\mathbf{7 3 \%}$ yield. The cyclopropyl analogues were prepared as a mixture of acid $\mathbf{5 7}$ and ester $\mathbf{5 8}$ by using Simmons-Smith reaction.

Minnikin and coworkers also synthesized a $\left(1^{\prime} R, 2^{\prime} S\right) \omega-19$ cyclopropane fatty acid containing 23-26 carbon chain-length range, which is related to mycobacterial mycolic acids (Scheme 13)[47]. For example, the 24-carbon $\omega-19$ cyclopropane ester 64 was prepared by chain elongation of the 23-carbon ester, which was prepared from D-manitol by the same methodology used by Minnikin mentioned above. The chain elongation was based on classic reactions, beginning with the reduction of ester group, tosylation of alcohol 61, introduction of cyano group followed by hydrolysis, and finally, esterification of acid 63 to furnish ester 64.

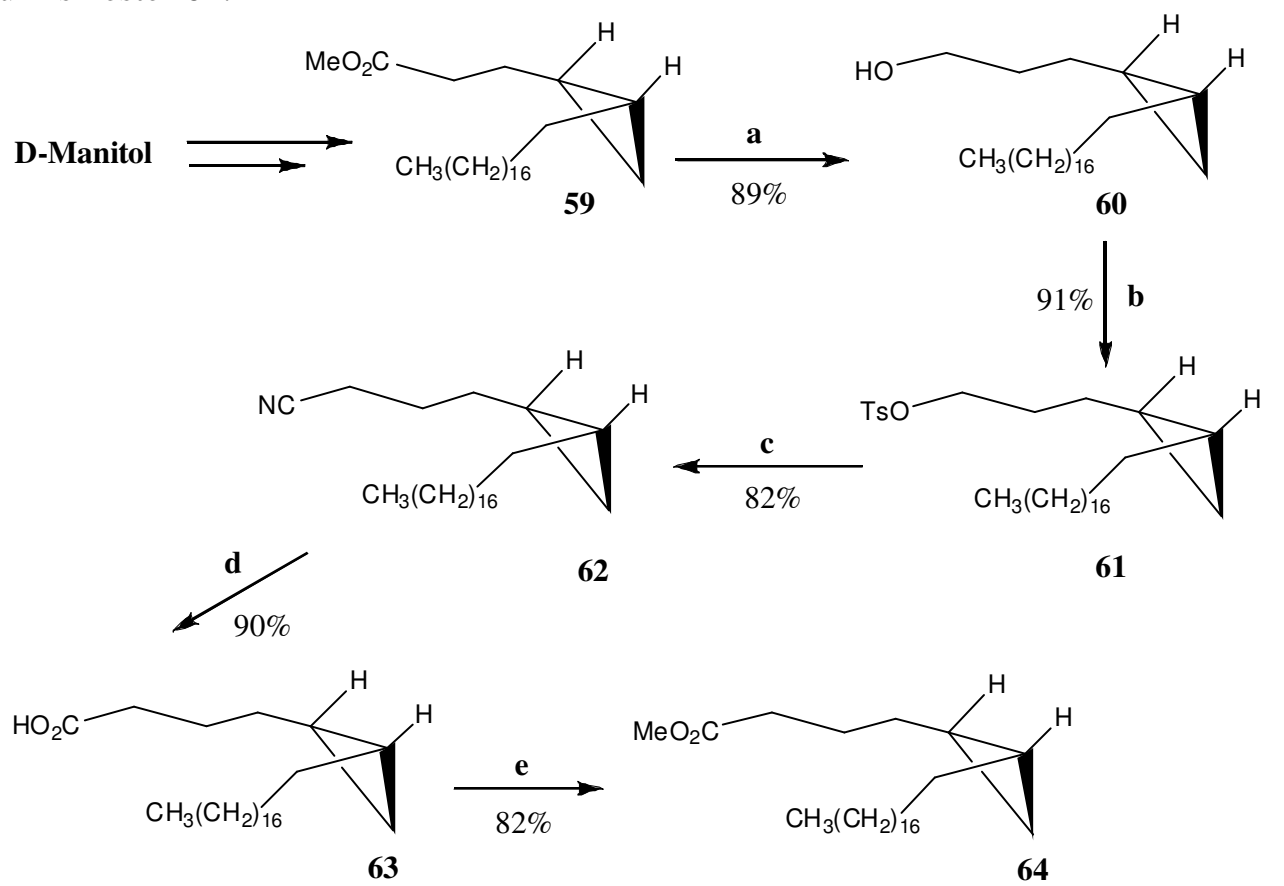

SCHEME 13. Synthesis of $\left(1^{\prime} R, 2^{\prime} S\right) \omega-19$ cyclopropane fatty acid containing $23-26$ carbon chain-length range proposed by Minnikin and coworkers. (a) $\mathrm{LiAlH}_{4}$, THF, reflux, $1 \mathrm{~h}$; (b) TsCl, pyridine, $0^{\circ} \mathrm{C}$-r.t.; (c) $\mathrm{NaCN}$, DMSO, $120^{\circ} \mathrm{C}, 2 \mathrm{~h}$; (d) $\mathrm{NaOH}$, EtOH, reflux, 3 h; (e) DOWEX - $\mathrm{H}^{+}$, MeOH, reflux, $3 \mathrm{~h}$. 
An important contribution in the mycolic acid field was also made by Baird and coworkers[48], who prepared an elegant synthesis of a mycolic acid $\mathbf{6 5}$ (Fig. 5). This deprotected compound was isolated from M. $t b$.

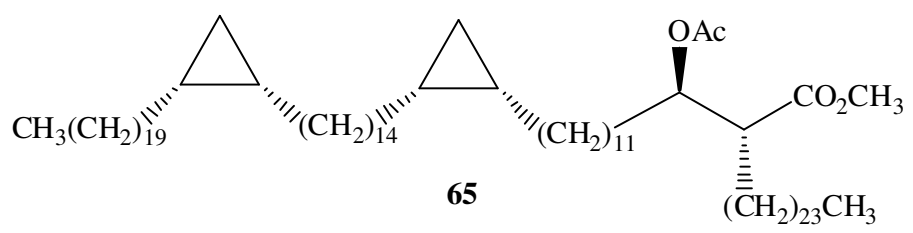

FIGURE 5. Mycolic acid 65 synthesized by Baird and coworkers.

The synthetic strategy of Baird for the preparation of mycolic acid 65 (Schemes 14-19) was based on construction method of the cyclopropyl ring used by Minnikin. In this context, the key intermediate $(1 R$, $2 S$ )-aldehyde 75 was prepared as shown in Scheme 15. First, the intermediate $\mathbf{7 1}$ was coupled with the ylid 76 obtained by treatment of 68 with $n-B u L i$. Compound 68 was prepared by two different methods as shown in Scheme 14. Compound 72 was transformed in aldehyde 74 (three steps), which was treated with 1-carbomethoxy-12-triphenylphosphoniumundecyliodide $\mathbf{7 7}$ in the presence of sodium methoxide, followed by reduction, hydrogenation, and oxidation to furnish $\mathbf{7 5}$.

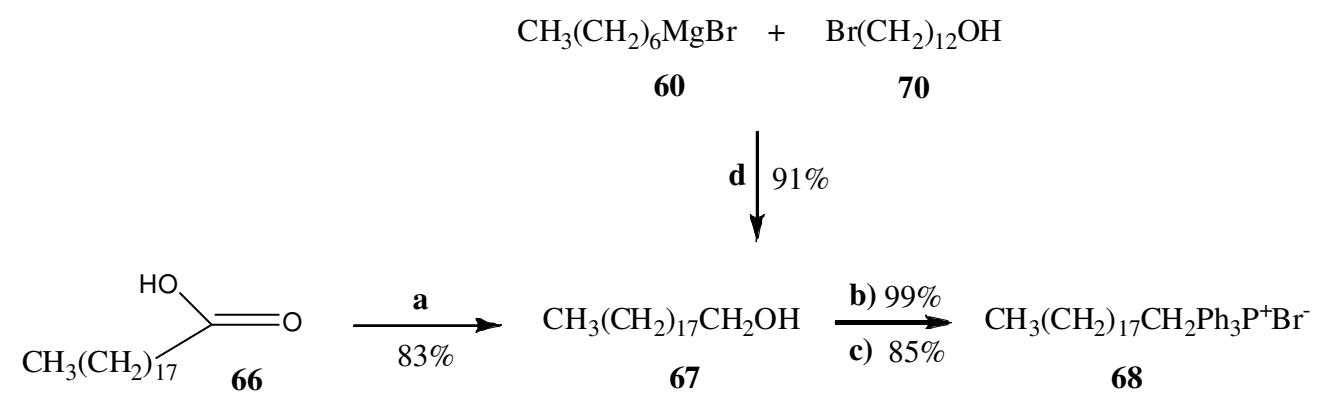

SCHEME 14. Synthesis of fragment 68 for the preparation of mycolic acid 65. (a) $\mathrm{LiALH}_{4}, \mathrm{THF}$; (b) aq. $\mathrm{HBr}$ $\mathrm{Bu}_{4} \mathrm{~N}^{+} \mathrm{Br}$; (c) $\mathrm{PPh}_{3}$, toluene; (d) $\mathrm{Li}_{2} \mathrm{CuCl}_{4}$, THF.

For the preparation of compound $\mathbf{8 1}$ bearing two cyclopropane rings (Scheme 16), the same synthetic strategy was used for the construction of the previous cyclopropyl aldehyde 75 (Scheme 15). However, the Wittig reaction coupling was changed by Julia reaction. First, the ester $\mathbf{7 8}$ was converted to sulfone $\mathbf{7 9}$ by reaction with 2-mercaptobenzothiazole, triphenylphosphine, and diethyl azodicarboxylate, followed by oxidation of the thioether intermediate. Sulfone $\mathbf{7 9}$ was coupled with $\mathbf{7 5}$ using a modified Julia reaction, which led to a 1:1 mixture of $E$ - and $Z$-alkenes 80, which, after reduction of carboxylic group and hydrogenation of double bond, furnished the alcohol $\mathbf{8 1}$.

The hydroxyl acid portion represented by other key intermediate $\mathbf{8 8}$ was prepared based on the epoxide 82, which was obtained from $(R)$-aspartic acid. Compound $\mathbf{8 2}$ was opened by Grignard reagent 83, leading to the di-protected triol $\mathbf{8 4}$ (Scheme 17). The later compound, after silylation, deprotection of benzyl group, alcohol oxidation, and esterification, led to the intermediate 85. Further, the primary hydroxyl group of this intermediate was selectively protected by using a hindered silyl group (TBDPS), followed by treatment with LDA and 1-iodotetracosane 86, previously prepared as described in Scheme 18, furnishing the hydroxyl ester $\mathbf{8 7}$. Finally, compound $\mathbf{8 7}$ was acetylated, the silyl group was removed, and the primary hydroxyl group generated was oxidated, leading to intermediate $\mathbf{8 8 .}$ 

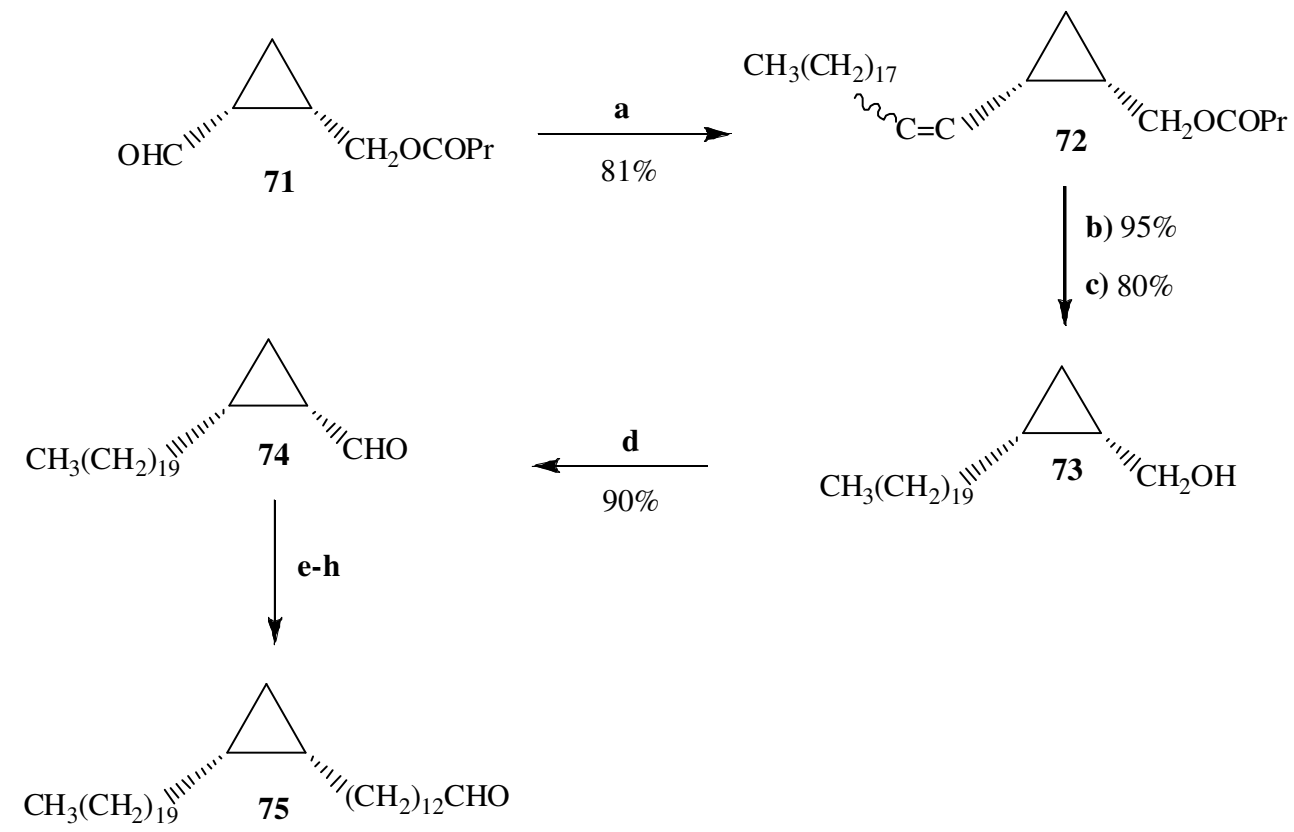

SCHEME 15. Synthesis of fragment $\mathbf{7 5}$ for the preparation of mycolic acid $\mathbf{6 5}$. (a) $\mathrm{Me}\left(\mathrm{CH}_{2}\right)_{18} \mathrm{PPh}_{3} \mathrm{Br}$, BuLi, THF (81\%, 6:1 Z/E); (b) $\mathrm{LiAlH}_{4}, \mathrm{THF}$; (c) $\mathrm{N}_{2} \mathrm{H}_{4}, \mathrm{NaIO}_{4}, \mathrm{AcOH}, \mathrm{CuSO}_{4}, i$-PrOH; (d) $\mathrm{PCC}, \mathrm{CH}_{2} \mathrm{Cl}_{2}$; (e) $\mathrm{CH}_{3} \mathrm{O}_{2} \mathrm{C}\left(\mathrm{CH}_{2}\right)_{11} \mathrm{PPh}_{3} \mathrm{I}$ (77), MeONa, THF, DMF (70\%); (f) $\mathrm{LiAlH}_{4}, \mathrm{THF}(92 \%)$; (g) $\mathrm{N}_{2} \mathrm{H}_{4}, \mathrm{NaIO}_{4}, \mathrm{AcOH}, \mathrm{CuSO} 4$, $i$-PrOH (85\%); (h) PCC, $\mathrm{CH}_{2} \mathrm{Cl}_{2}(93 \%)$.

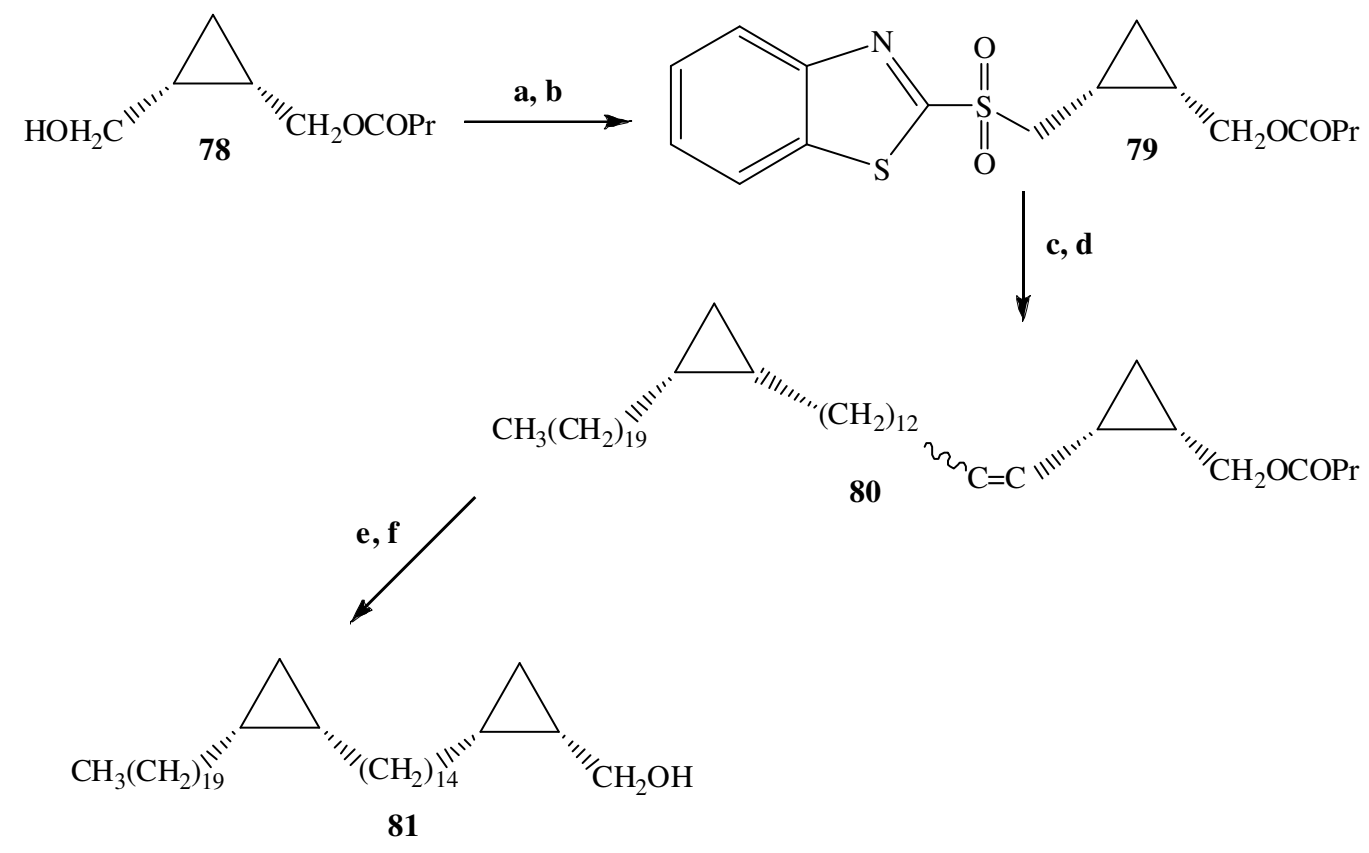

SCHEME 16. Synthesis of fragment 81 for the preparation of mycolic acid 65. (a) 2-Mercaptobenzothiazole, $\mathrm{PPh}_{3}$, DEAD, 81\%; (b) $\mathrm{H}_{2} \mathrm{O}_{2}$ or MCPBA, $\mathrm{CH}_{2} \mathrm{Cl}_{2}$; (c) LiHMDS; (d) (75) (43\% two steps; (e) $\mathrm{LiAlH}_{4}$, THF; (f) $\mathrm{NH}_{2} \mathrm{NH}_{2}$, $\mathrm{NaIO}_{4}, \mathrm{CuSO}_{4}, \mathrm{AcOH}, i$-PrOH (77\% two steps). 


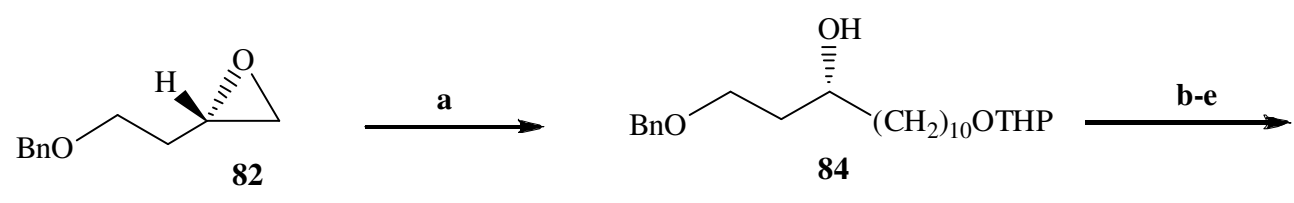

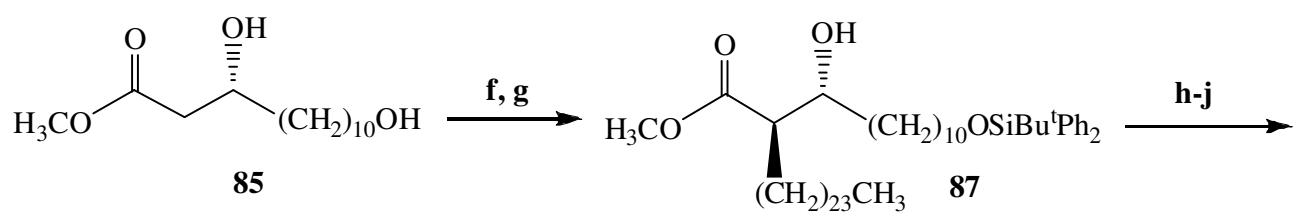

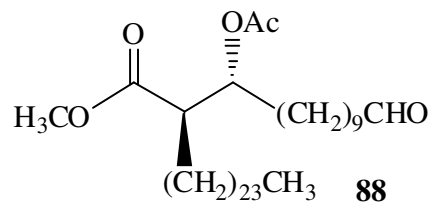

SCHEME 17. Synthesis of fragment 88 for the preparation of mycolic acid 65. (a) $\mathrm{BrMg}\left(\mathrm{CH}_{2}\right)_{9} \mathrm{OTHP}(\mathbf{8 3})$, CuI, 2 h, $-30^{\circ} \mathrm{C}, 86 \%$; (b) imidazole, DMF, $\mathrm{Bu}^{\mathrm{t} S i M e} \mathrm{Si}_{2} \mathrm{Cl}, 93 \%$; (c) $\mathrm{H}_{2}, \mathrm{Pd} / \mathrm{C}, \mathrm{MeOH}, 84 \%$; (d) $\mathrm{NaIO}_{4}, \mathrm{RuCl}_{3} \cdot \mathrm{H}_{2} \mathrm{O}, \mathrm{CH}_{3} \mathrm{CN}$, $\mathrm{H}_{2} \mathrm{O}, \mathrm{CCl}_{4}, 69 \%$; (e) $\mathrm{MeOH}, \mathrm{H}_{2} \mathrm{SO}_{4}\left(69 \%\right.$ ); (f) $\mathrm{Bu}^{t} \mathrm{Ph}_{2} \mathrm{SiCl}$, DMAP, Et $3 \mathrm{~N}, 84 \%$; (g) LDA, $\mathrm{CH}_{3}\left(\mathrm{CH}_{2}\right)_{23} \mathrm{I}$ (86), HMPA, $31 \%$; (h) $\mathrm{Ac}_{2} \mathrm{O}$, pyridine, $86 \%$; (i) HF.py $75 \%$; (j) $\mathrm{PCC}, \mathrm{CH}_{2} \mathrm{Cl}_{2} 95 \%$.

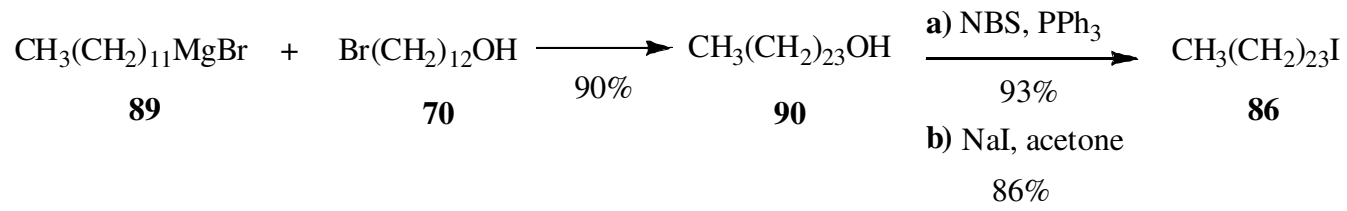

SCHEME 18. Synthesis of iodine derivative 86 for the preparation of mycolic acid $\mathbf{6 5}$.<smiles>CCCCC[C@@H]1C[C@@H]1C[C@@H]1C[C@H]1CS(=O)(=O)c1nc2ccccc2s1</smiles>

SCHEME 19. Final steps for the preparation of mycolic acid 65. (a) 2-Mercaptobenzothiazole, $\mathrm{PPh}_{3}, \mathrm{DEAD}$; (b) MCPBA, $\mathrm{CH}_{2} \mathrm{Cl}_{2}, 66 \%$; (c) LiBSA; (d) (88); (e) potassium azodicarboxylate, AcOH, THF. 
The final steps for the production of the protected mycolic acid $\mathbf{6 5}$ is described in Scheme 19. The sulfone 91 was coupled with the aldehyde $\mathbf{8 8}$ using Julia reaction conditions, leading to a mixture of $E$ and $Z$ alkenes $\mathbf{9 2}$, followed by hydrogenation to produce the desired protected mycolic acid $\mathbf{6 5}$.

The synthetic strategy used by Baird and coworkers described above to produce the mycolic acid $\mathbf{6 5}$ (Fig. 5) also allowed the synthesis of a different fragment of mycolic acids[49]. For example, Baird and coworkers also synthesized an enantiomer $\alpha$-methyl-trans-cyclopropane unit 93 (Fig. 6), which is present in different mycolic acids.

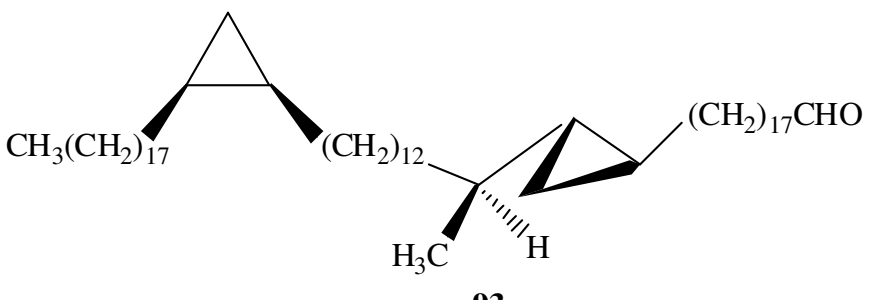

93

FIGURE 6. Structure of $\alpha$-methyl-trans-cyclopropane unit 93.

These authors also developed an improved procedure for the preparation of $\beta$-hydroxy- $\alpha$-alkyl fatty acid 94 (Fig. 7), a fragment of mycolic acids, which could be used for the preparation of different compounds of this class[50]. In this context, the synthesis of fragment 94 (Schemes 20 and 21) started with mono protection of the diol $\mathbf{9 5}$. Oxidation followed by Wittig reaction led to ester $\alpha, \beta$-unsaturated 97 (Scheme 20). Sharpless oxidation of intermediate 97 was followed by conversion into cyclic sulfate 99, which was regioselectively reduced and hydrolyzed to produce the (3R)-3-hydroxy ester 100. The introduction of allyl chain in $\mathbf{1 0 0}$ led to $(2 R, 3 R)$-2-allyl-3-hydroxy ester 101. Secondary alcohol of 101 was protected with silyl group and then conversion to aldehyde $\mathbf{1 0 3}$ was performed by transforming the double bond of 102 into diol group by reaction with $\mathrm{OsO}_{4}$, followed by oxidative cleavage with $\mathrm{NaIO}_{4}$ (Scheme 20). Aldehyde 103 was coupled with sulfone 105 using Julia reaction conditions to furnish compound 106, which after hydrogenation, cleavage of the pivaloyl group, and oxidation of the alcohol to aldehyde, gave the key intermediate 94 (Scheme 21).

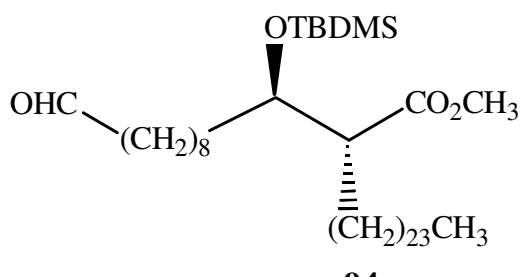

94

FIGURE 7. Structure of $\beta$-hydroxy- $\alpha$-alkyl fatty acid 94.

\section{NEW COMPOUNDS AND CLASSES THAT ACT IN THE MYCOBACTERIUM TUBERCULOSIS CELL WALL}

Due to the importance of the $M$. $t b$. cell wall in drug discovery, several research groups have identified between 2005 and 2007 new compounds and classes with promising perspectives. 


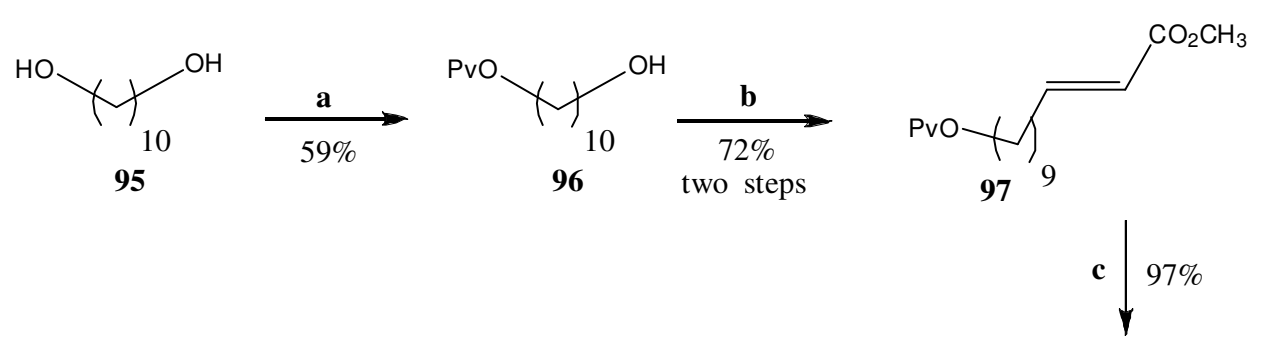

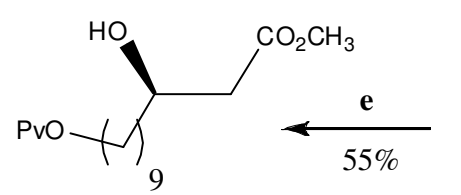

100
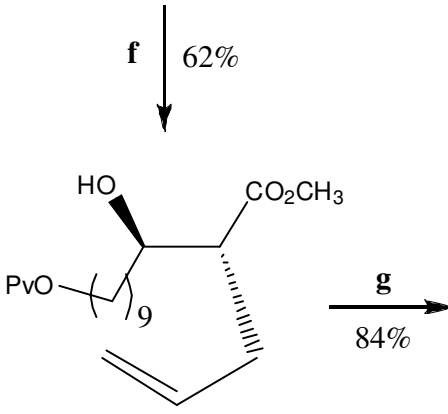

101
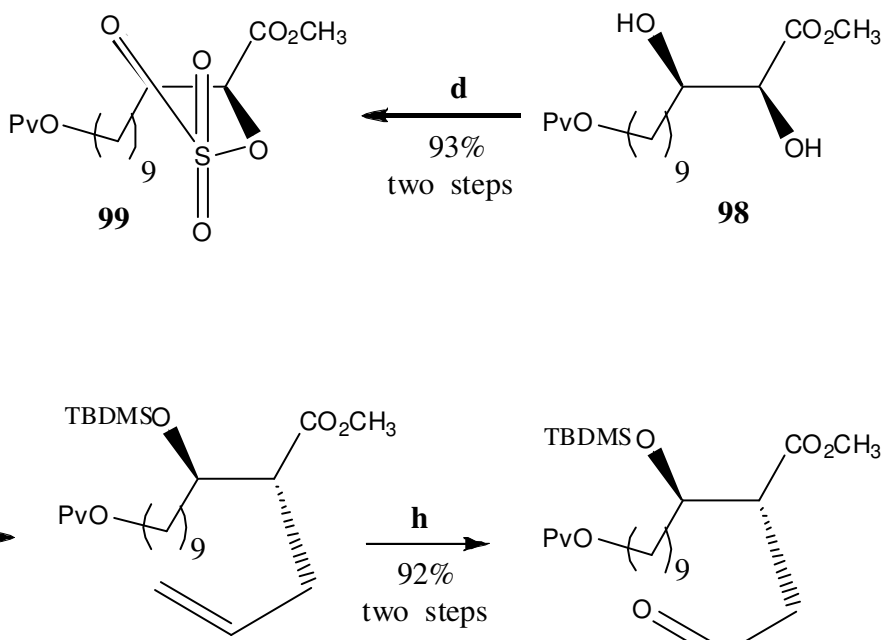

102

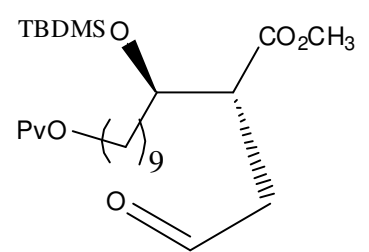

103

SCHEME 20. Synthesis of the intermediate 103 for the preparation of $\beta$-hydroxy- $\alpha$-alkyl fatty acid 94. (a) (i) $\mathrm{PvCl}$ (1.1 mol.equiv.), $\mathrm{Et}_{3} \mathrm{~N}$ (3 mol.equiv.), THF, $\mathrm{CH}_{2} \mathrm{Cl}_{2}$; (ii) $\mathrm{KOH}$ (2 mol.equiv.), $\mathrm{MeOH}, \mathrm{H}_{2} \mathrm{O}$, (59\%); (b) (i) PCC (2 mol.equiv.), $\mathrm{CH}_{2} \mathrm{Cl}_{2}$; (ii) $\mathrm{Ph}_{3} \mathrm{P}=\mathrm{CHCO}_{2} \mathrm{Me}$ (1.1 mol.equiv.), toluene (72\%); (c) (DHQD) $)_{2} \mathrm{PHAL}\left(1 \mathrm{~mol} \%\right.$ ), $\mathrm{K}_{3} \mathrm{Fe}(\mathrm{CN})_{6}$ (3 mol.equiv.), $\mathrm{K}_{2} \mathrm{CO}_{3}$ (3 mol.equiv.), $\mathrm{OsO}_{4}$ (4 mol.\%), $\mathrm{MeSO}_{2} \mathrm{NH}_{2}$ (1 mol.equiv.), ${ }^{\mathrm{BuOH}} \mathrm{H}_{2} \mathrm{O}$ (97\%); (d) (i) $\mathrm{SOCl}_{2}$, (2 mol.equiv.), $\mathrm{CCl}_{4}$; (ii) $\mathrm{NaIO}_{4}$ (1.5 mol.equiv.), $\mathrm{RuCl}_{3} \cdot \mathrm{H}_{2} \mathrm{O}$, (5 mol.\%) in $\mathrm{CCl}_{4}, \mathrm{CH}_{3} \mathrm{CN} . \mathrm{H}_{2} \mathrm{O}$ (93\%); (e) $\mathrm{NaBH}_{4}(1$ mol.equiv.), $\mathrm{N}, \mathrm{N}$-dimethylacetamide; $\mathrm{H}_{2} \mathrm{SO}_{4}$, ether, (55\%); (f) LDA (2.5 mol.equiv.), THF, $\mathrm{CH}_{2}=\mathrm{CHCH}_{2} \mathrm{I}, \quad(1.5$ mol.equiv.), HMPA (2 mol.equiv.), THF, (62\%); (g) TBDMSCl (1.4 mol.equiv.) imidazole (2.5 mol.equiv.), DMF (84\%); (h) (i) $\mathrm{OsO}_{4}\left(4\right.$ mol.\%), 2,6-lutidine (2 mol.equiv.), (ii) $\mathrm{NaIO}_{4}\left(2.5\right.$ mol.equiv.) dioxane, $\mathrm{H}_{2} \mathrm{O}(92 \%)$.

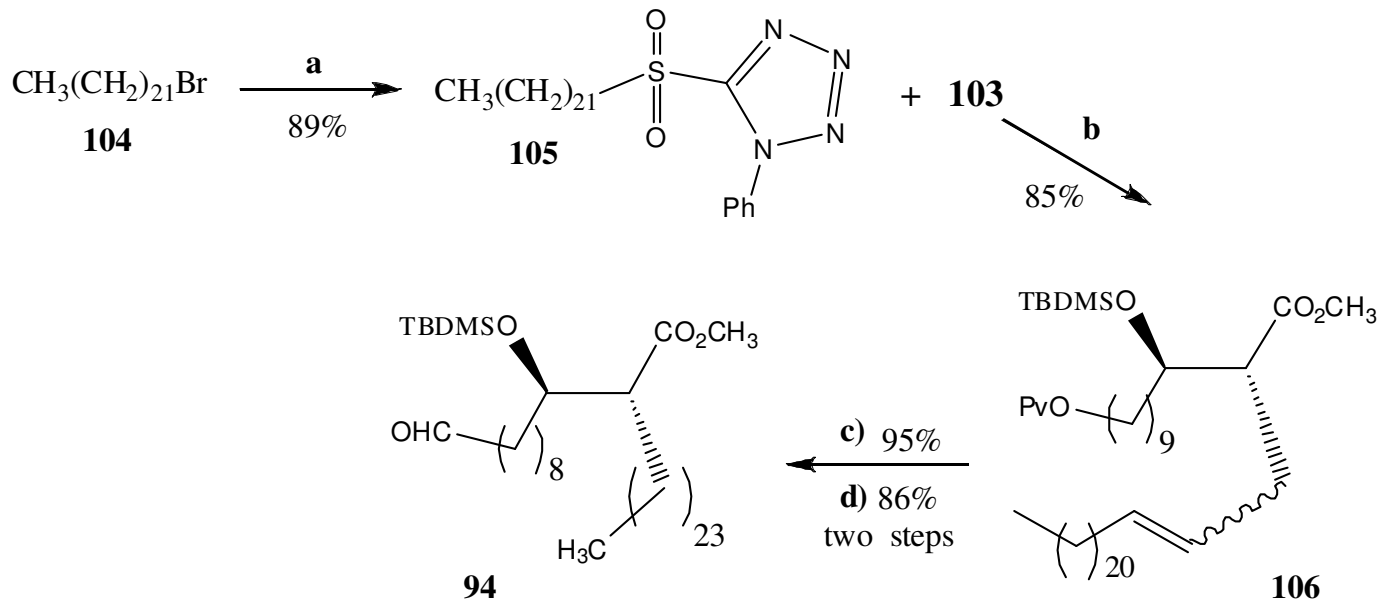

SCHEME 21. Final steps for the preparation of $\beta$-hydroxy- $\alpha$-alkyl fatty acid 94. (a) (i) 1-Phenyl- $1 H$-tetrazole-5-thiol (1.05 mol.equiv.), $\mathrm{K}_{2} \mathrm{CO}_{3}$ (1.5 mol.equiv.), acetone; (ii) $\mathrm{H}_{2} \mathrm{O}_{2}$ (47 mol.equiv.), $\left(\mathrm{NH}_{4}\right)_{6} \mathrm{Mo}_{7} \mathrm{O}_{24} .4 \mathrm{H}_{2} \mathrm{O}$ (5.5 mol.\%.), THF, IMS (89\%); (b) $\mathrm{LiN}\left(\mathrm{Si}(\mathrm{Me})_{3}\right)_{2}$ (1.5 mol.equiv.), THF, then 103 (85\%); (c) $\mathrm{H}_{2}, \mathrm{Pt} / \mathrm{C}, \mathrm{CH}_{3} \mathrm{CO}_{2} \mathrm{Et}$, IMS (95\%); (d) (i) $\mathrm{KOH}$, THF, $\mathrm{MeOH}, \mathrm{H}_{2} \mathrm{O}$; (ii) $\mathrm{PCC}, \mathrm{CH}_{2} \mathrm{Cl}_{2}(86 \%)$. 


\section{Isoniazid Analogues}

Despite the role of isoniazid as an essential drug in TB treatment, there are some problems during its utilization, such as side effects, inefficiency against MDR strains, and duration of the treatment. In an attempt to solve these problems, several analogues have been synthesized by different groups[51]. Arora and coworkers[52] recently synthesized a series of isoniazid analogues: compound 107 (Fig. 8) demonstrated similar in vitro activity compared to isoniazid against $M . t b . \mathrm{H}_{37} \mathrm{Rv}$ and clinically sensitive strains, as well as superior activity against MDR strains (see Table 2).

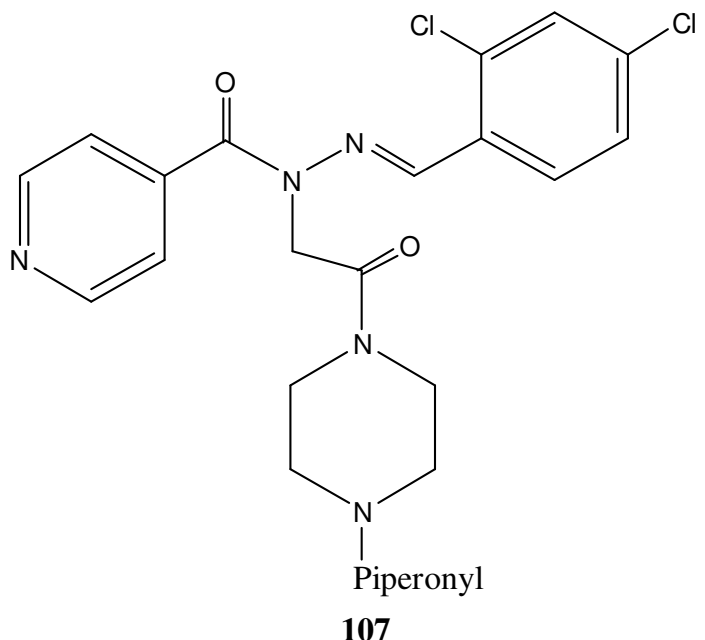

FIGURE 8. Structure of compound 107.

TABLE 2

Comparative MIC Values $(\mu \mathrm{g} / \mathrm{ml})$ between Compound 107 and Isoniazid

\begin{tabular}{lccc}
\hline Compound & $\begin{array}{c}\text { M. } \boldsymbol{t b} . \\
\mathbf{H}_{37} \mathbf{R v}\end{array}$ & $\begin{array}{c}\text { M. tb. } \\
\text { Clinically Sensitive }\end{array}$ & $\begin{array}{c}\text { M. } \boldsymbol{t b} . \\
\text { MDR }\end{array}$ \\
\hline 107 & 1.0 & $0.25-0.5$ & $2-4$ \\
Isoniazid & 0.25 & $0.12-0.25$ & $8->16$ \\
\hline
\end{tabular}

\section{Thiocarlide (Isoxyl) Analogues}

The thiourea known as thiocarlide (isoxyl) (Fig. 9) was used in the 1960s to treat TB. However, nowadays, this drug has regained special attention due to its promising in vitro antimycobacterial activity between 1-10 $\mu \mathrm{g} / \mathrm{ml}$ against different clinical MDR strains[53]. Hence, Besra and coworkers synthesized and evaluated different symmetrical and unsymmetrical analogues of isoxyl against $M . t b . \mathrm{H}_{37} \mathrm{Rv}$ and $M$. bovis BCG with promising results (Fig. 9)[54]. Compounds 1-(p-n-butylphenyl)-3-(4-propoxyphenyl) thiourea 108 and 1-( $p$-n-butylphenyl)-3-(4-n-butoxyphenyl) thiourea 109, in particular, when compared to isoxyl, have demonstrated a nearly tenfold increase in in vitro activity in the inhibition of mycolic acid biosynthesis in $M$. bovis BCG. Another important fact provided by these compounds was that their poor inhibition of oleate production indicated that the modifications made in the aromatic ring have an influence in the biological activity. 


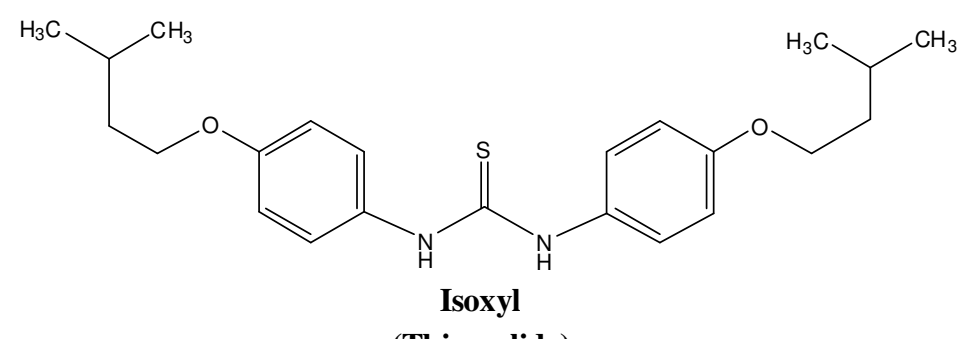

(Thiocarlide)<smiles>[R]c1ccc(NC(=S)Nc2ccc(Br)cc2)cc1</smiles>

$$
\begin{aligned}
& 108-\mathrm{R}^{1}=\mathrm{O}\left(\mathrm{CH}_{2}\right)_{2} \mathrm{CH}_{3} \quad \mathrm{R}^{2}=\left(\mathrm{CH}_{2}\right)_{3} \mathrm{CH}_{3} \quad \mathbf{1 0 9}-\mathrm{R}^{1}=\mathrm{O}\left(\mathrm{CH}_{2}\right)_{3} \mathrm{CH}_{3} \quad \mathrm{R}^{2}=\left(\mathrm{CH}_{2}\right)_{3} \mathrm{CH}_{3} \\
& \text { M. tb. } \quad \operatorname{MIC}_{99}(\mu \mathrm{g} / \mathrm{mL})=<0.1 \quad \text { M.tb. } \quad \mathrm{MIC}_{99}(\mu \mathrm{g} / \mathrm{mL})=<0.1 \\
& \text { M. bovis. } \mathrm{MIC}_{99}(\mu \mathrm{g} / \mathrm{mL})=0.06 \quad \text { M. bovis. } \mathrm{MIC}_{99}(\mu \mathrm{g} / \mathrm{mL})=0.7 \\
& \text { BCG } \\
& \text { BCG }
\end{aligned}
$$

FIGURE 9. Structures of thiocarlide (isoxyl) and compounds 108 and 109.

\section{Ethambutol Analogues}

An important work published in 2005 in the field of drug discovery was the study of Protopopova and coworkers[55] in collaboration with Clif Barry (NIH/NIAID), which built a library of 63,238 compounds based on 1,2-ethylenediamine, the pharmacophore of ethambutol. These compounds were evaluated against $M$. $t b$. and 26 demonstrated in vitro activity equal to or greater (up to 14-fold) than ethambutol. The compound named SQ109 (Fig. 10) was selected for further development due to its potent activity, MIC $0.7-1.56 \mu \mathrm{g} / \mathrm{ml}$, an SI of 16.7, and 99\% inhibition activity against intracellular bacteria. Additionally, it has demonstrated potency in vivo and limited toxicity in vitro and in vivo.

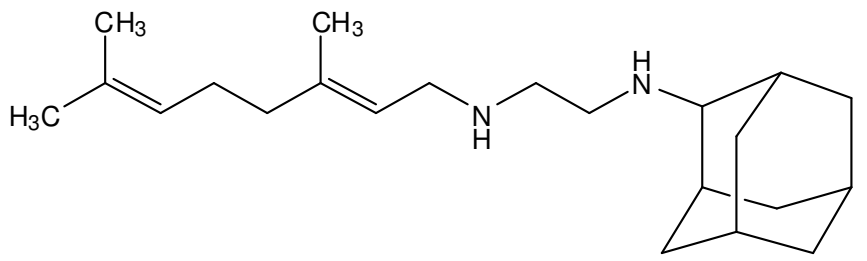

$\operatorname{MIC}(\mathrm{mg} / \mathrm{mL})=0.7-1.5$

SI of 16.7 and $99 \%$ inhibition activity against intracellular bacteria

FIGURE 10. Structure of compound SQ109.

Pélinski and coworkers synthesized (Scheme 22) and evaluated (Table 3) the anti-TB activity of ferrocenyl ethambutol analogues and ferrocenyl diamines[56]. Preliminary studies demonstrated that the ferrocenyl diamines 111 and 112 displayed good activities against $M . t b . \mathrm{H}_{37} \mathrm{Rv}$. These ferrocenyl analogues were synthesized in 46-77\% yield by reacting ferrocene carboxaldehyde 110 with the respective diamines, followed by reduction with $\mathrm{NaBH}_{4}$. 


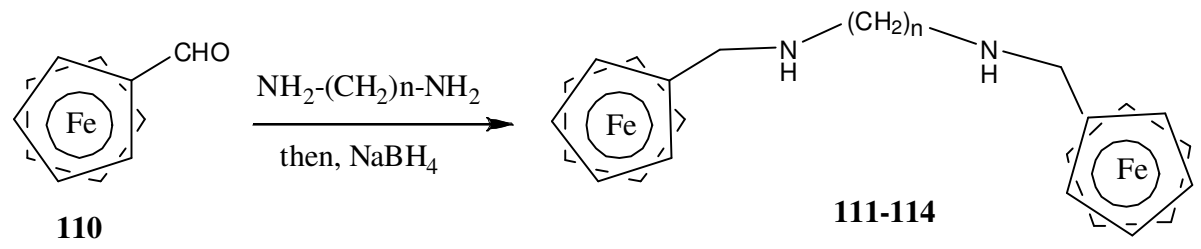

SCHEME 22. Structures of ferrocenyl diamines 111 and 112.

TABLE 3

MIC Values of Compounds 111-114 against $M$. tb.

\begin{tabular}{lccc}
\hline $\mathbf{N}^{\mathbf{o}}$ & $\mathbf{n}$ & $\boldsymbol{M} . \boldsymbol{t} \boldsymbol{t} . \mathbf{M I C}(\boldsymbol{\mu g} / \mathbf{m l})$ & Overall Yield (\%) \\
\hline 111 & 2 & 8 & 76 \\
112 & 3 & 8 & 54 \\
113 & 4 & 32 & 77 \\
114 & 6 & 32 & 46 \\
\hline
\end{tabular}

Tripathi and coworkers described the synthesis and biological evaluation (Scheme 23) of galactopyranosyl amino alcohols as a new class of anti-TB agents[57]. The synthesis was based on the introduction of epichlorohydrin in the diacetonide- $\alpha$-D-galactose $\mathbf{1 1 5}$, followed by regioselective oxirane ring opening with several diamines furnishing amino alcohols with two galactopyranosyl units. Compound 117 demonstrated potent in vitro activity against $\mathrm{H}_{37} \mathrm{Rv}$ and $\mathrm{MDR} M$. $t b .(1.56 \mu \mathrm{g} / \mathrm{ml})$ when compared with ethambutol $(3.25 \mu \mathrm{g} / \mathrm{ml})$ (Scheme 23).
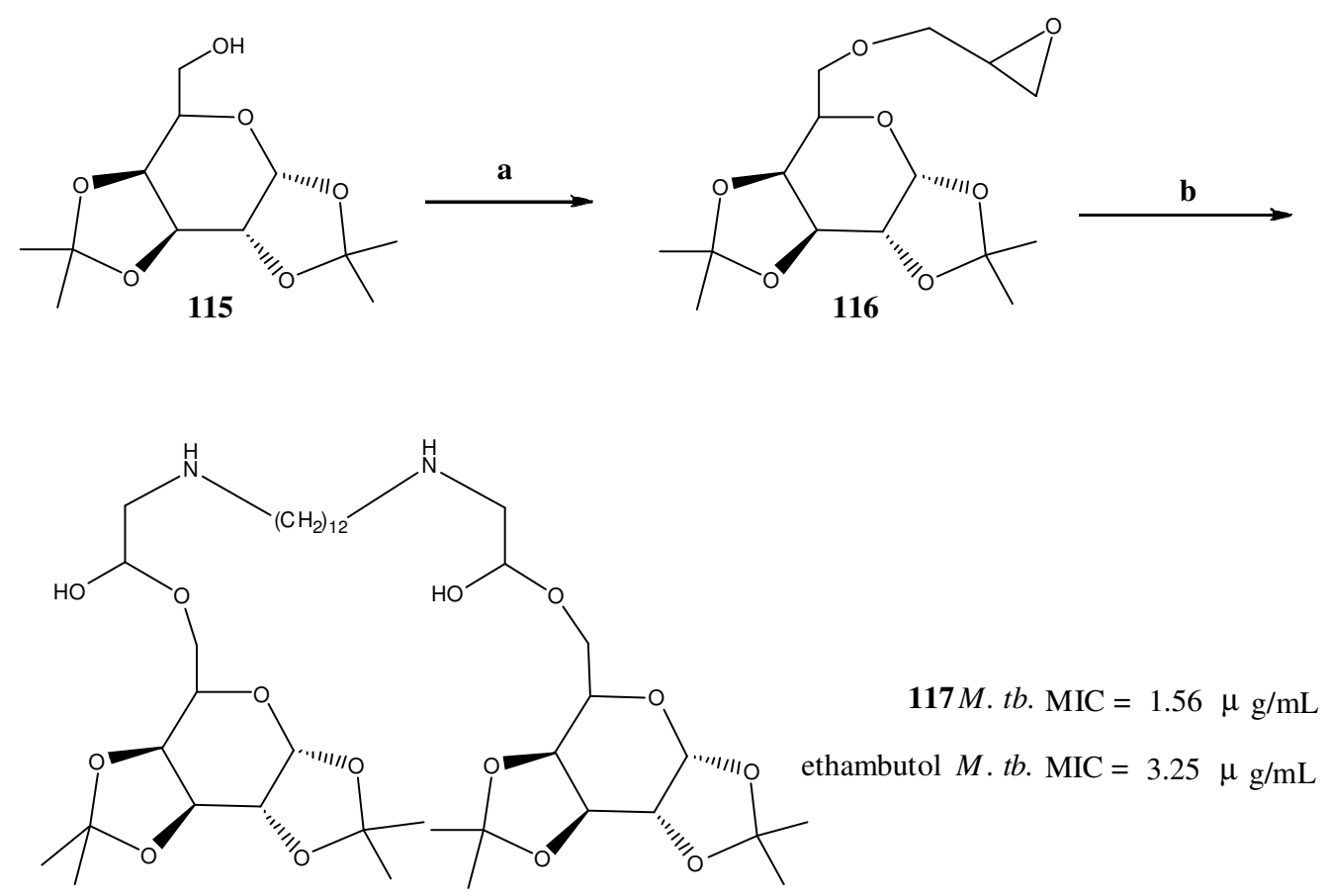

SCHEME 23. Synthesis of galactopyranosyl amino alcohol 117. (a) Epichlorohydrin, aq. NaOH, THF, tetrabutyl ammonium bromide, $40^{\circ} \mathrm{C}, 12 \mathrm{~h}$; (b) $\mathrm{NH}_{2}\left(\mathrm{CH}_{2}\right)_{\mathrm{n}} \mathrm{NH}_{2}$; ethanol, $30^{\circ} \mathrm{C}, 12-18 \mathrm{~h}$. 
Tripathi and coworkers also described the synthesis (Fig. 11) of glycosylated amino alcohols by classical carbohydrate chemistry, which were evaluated (Table 4) against $M . t b . \mathrm{H}_{37} \mathrm{Ra}$ and $\mathrm{H}_{37} \mathrm{Rv}$ [58]. The most promising compounds were 118 and 119, presenting MIC ranging from 6.25 to $3.12 \mu \mathrm{g} / \mathrm{ml}$.
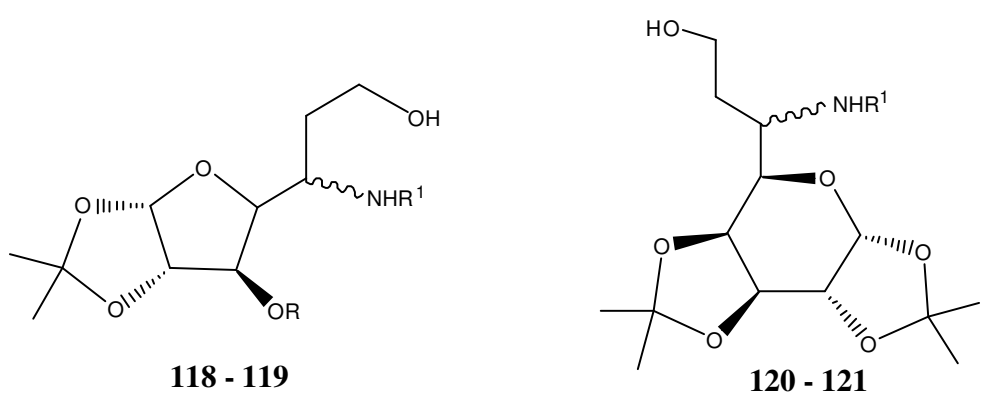

FIGURE 11. Structures of glycosylated amino alcohols 118-121.

TABLE 4

MIC values of Compounds 118-121

\begin{tabular}{|c|c|c|c|c|}
\hline $\mathbf{N}^{\circ}$ & $\mathbf{R}$ & $\mathbf{R}^{1}$ & $\begin{array}{c}\text { M. tb. MIC }(\mu \mathrm{g} / \mathrm{ml}) \\
\mathrm{H}_{37} \mathrm{Ra}\end{array}$ & $\begin{array}{c}\text { M. tb. MIC }(\mu \mathrm{g} / \mathrm{ml}) \\
\mathrm{H}_{37} \mathrm{Rv}\end{array}$ \\
\hline 118 & $\mathrm{CH}_{3}$ & $\left(\mathrm{CH}_{2}\right)_{15} \mathrm{CH}_{3}$ & 6.25 & 6.25 \\
\hline 119 & $\mathrm{CH}_{2} \mathrm{Ph}$ & $\left(\mathrm{CH}_{2}\right)_{11} \mathrm{CH}_{3}$ & 3.12 & 3.12 \\
\hline 120 & - & Oleyl & 3.12 & 6.25 \\
\hline 121 & - & $\left(\mathrm{CH}_{2}\right){ }_{15} \mathrm{CH}_{3}$ & 25 & 3.12 \\
\hline
\end{tabular}

A new class of aryloxyphenyl cyclopropyl methanone derivatives was discovered by Tripathi and coworkers[59], which was synthesized by using one-pot reaction between compound 122 with 12 different alcohols 123 (Scheme 24). Compounds of this class have been evaluated against $M . t b . \mathrm{H}_{37} \mathrm{Rv}$ in vitro and presented MICs ranging from 25 to $3.12 \mu \mathrm{g} / \mathrm{ml}$ (Table 5).

\section{PA-824}

Some classes of compounds containing nitro groups are under investigation as anti-TB drugs; the leader is represented as PA-824 (Fig. 12). This nitroimidazole was developed by PathoGenesis Inc. in 1995 for cancer treatment. However, despite its promising TB activity reported in 2000, when Chiron took over PathoGenesis Inc. in 2000, the project was aborted. However, TB Alliance and Chiron signed a license agreement that gave TB Alliance rights to develop this molecule. PA-824 has shown potent in vitro activity against $M$. $t b$. with MIC of $0.03-0.2 \mu \mathrm{g} / \mathrm{ml}[60]$. This compound also possesses high activity in mice with no toxicity in rodent models, as well as excellent sterilizing activity compared with isoniazid and rifampin. The mechanism of action of this prodrug, which requires activation, is due to a flavinoid known as F-420 cofactor, which activates PA-824, which subsequently inhibits the synthesis of protein and cell wall lipids. Due to its important results, PA-824 is under clinical phase. 


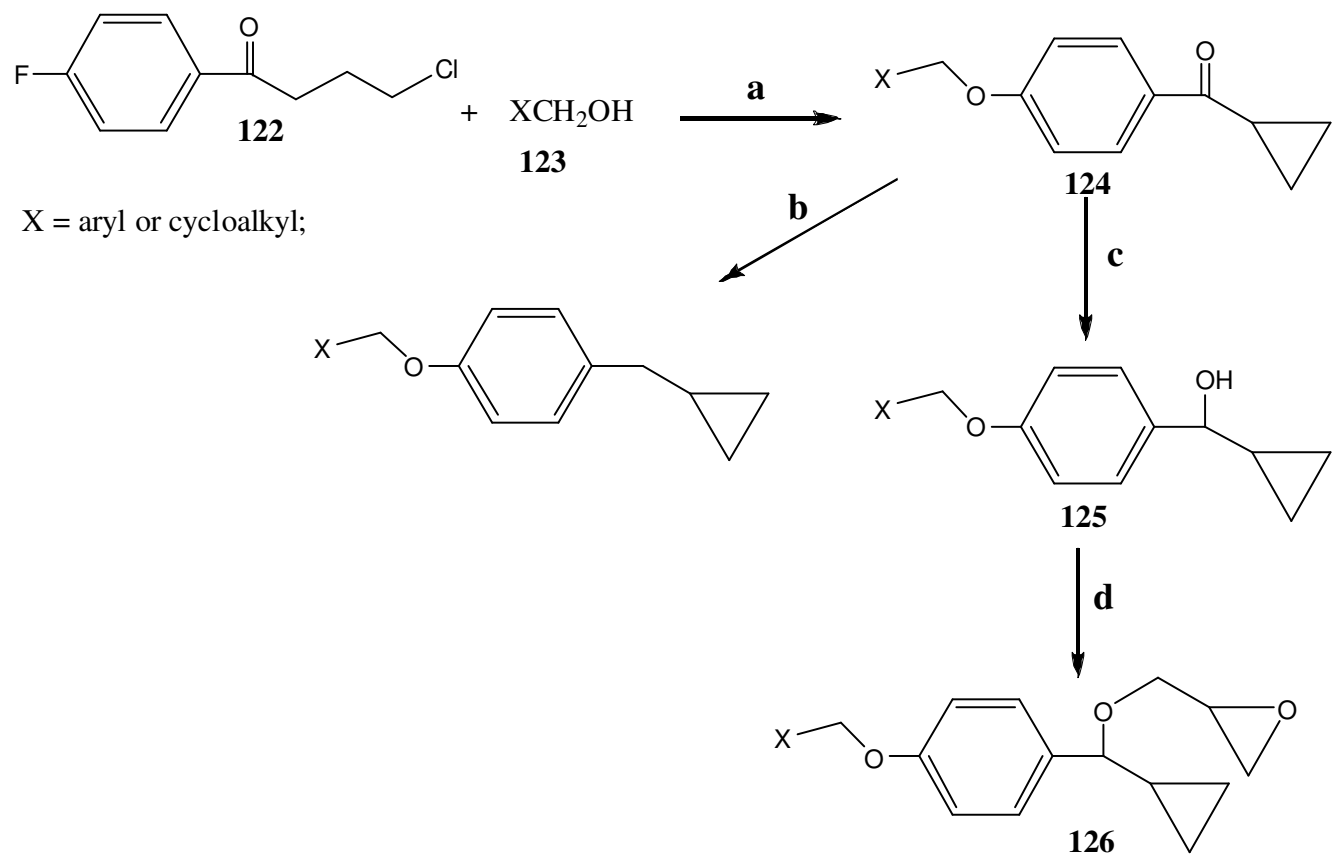

SCHEME 24. Structure of aryloxyphenyl cyclopropyl methanone derivative 126. (a) $\mathrm{NaH}, \mathrm{THF}, \mathrm{TBAB}, 0-30^{\circ} \mathrm{C}$; (b) $\mathrm{NH}_{2} \mathrm{NH}_{2} .2 \mathrm{HCl}$, diethylene glycol, $190^{\circ} \mathrm{C}$; (c) $\mathrm{NaBH}_{4}$, methanol, $0-25^{\circ} \mathrm{C}$; (d) epichlorohydrin, $\mathrm{NaH}, \mathrm{THF}, \mathrm{TBAB}, 0$ $25^{\circ} \mathrm{C}$.

\section{TABLE 5}

In vitro Anti-TB Activity of More Active Methanone Derivatives 124-126 $(\mu \mathrm{g} / \mathrm{ml})$ Prepared by Tripathi and coworkers[59]

\begin{tabular}{lccc}
\hline $\mathbf{N}^{\mathbf{0}}$ & $\mathbf{X}$ & MABA $\boldsymbol{M} . \mathbf{t b} . \mathbf{H}_{\mathbf{3} 7} \mathbf{R a}$ & Agar Microdilution $\mathbf{M . t b} . \mathbf{H}_{\mathbf{3}} \mathbf{R v}$ \\
\hline 124 & Phenyl & 25 & 6.25 \\
125 & 4-Methoxy phenyl & $>50$ & 3.12 \\
125 & 4-Fluoro phenyl & 25 & 6.25 \\
125 & Cyclopentyl & 25 & 3.12 \\
126 & 4-Fluoro phenyl & nd & 3.12 \\
\hline
\end{tabular}<smiles>O=[N+]([O-])c1cn2c(n1)OC[C@@H](OCc1ccc(C(F)(F)F)cc1)C2</smiles>

FIGURE 12. Structure of PA-824. 


\section{Nitrofuranylamides}

Lee and coworkers made a synthesis and biological evaluation (Table 6) of a series of nitrofuranylamides (Fig. 13) as anti-TB agents, with promising results[61]. These results were based on the activity of compound 127, discovered by a screen for $M$. $t b$. UDP-Gal mutase (Glf) inhibition, which possesses IC $_{50}$ of $12 \mu \mathrm{M}$ Glf inhibitor and MIC of $1.6 \mu \mathrm{g} / \mathrm{ml}$. For example, compounds 127-131 (Fig. 13) have been evaluated in vitro and in vivo with favorable perspectives. It is important to mention that, as mycolic acid, galactofuranose is an essential component of the mycobacterial cell wall, of which UDP-galactofuranose is biosynthesized from UDP-galactopyranose by using the enzyme UDP-galactose mutase[62,63].

TABLE 6

In vitro anti-TB Activity of Compounds 127-131

\begin{tabular}{lccccc}
\hline $\mathbf{N}^{\mathbf{0}}$ & $\mathbf{R}$ & $\mathbf{R}^{\mathbf{1}}$ & $\mathbf{n}$ & $\boldsymbol{M} . \boldsymbol{t} \boldsymbol{b} . \mathbf{M I C}(\boldsymbol{\mu g} \mathbf{g} \mathbf{m I})$ & Glf IC $_{\mathbf{5 0}}(\boldsymbol{\mu} \boldsymbol{M})$ \\
\hline 127 & $\mathrm{Cl}$ & $\mathrm{OCH}_{3}$ & 0 & 1.6 & 12 \\
128 & $\mathrm{Cl}$ & $\mathrm{H}$ & 0 & 0.8 & 15 \\
129 & $\mathrm{~F}$ & $\mathrm{H}$ & 0 & 0.8 & 28 \\
130 & $\mathrm{OCH}_{3}$ & $\mathrm{H}$ & 0 & 0.8 & 42 \\
131 & $\mathrm{OCH}_{3}$ & $\mathrm{OCH}_{3}$ & 1 & 0.2 & 23 \\
\hline
\end{tabular}

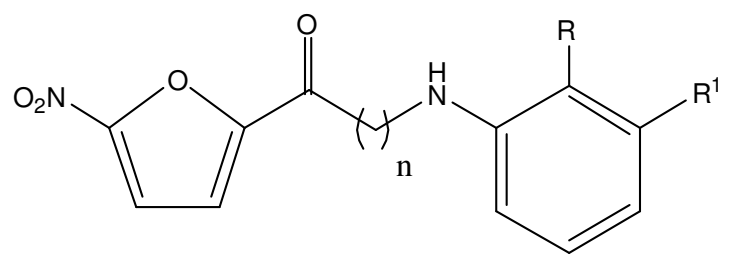

FIGURE 13. Structures of nitrofuranylamides 127-131.

\section{Thiolactomycin}

Thiolactomycin 1 (TLM, Fig. 14) is a naturally occurring antibiotic obtained from the fermentation broth of a strain of actinomycetes belonging to the genre Nocardia sp., found in a Japanese soil sample and described for the first time in 1982 by Oishi and coworkers[64]. TLM exhibits a broad spectrum of activity in vivo against many pathogenic micro-organisms, such as Gram-positive, Gram-negative, and anaerobic bacteria. TLM shows modest activity against laboratory strains of $M$. $t b$. (MIC $=62.5 \mu \mathrm{g} / \mathrm{ml}$ ). However, this natural product possesses relevant activity against several strains of $M$. $t b$., which are resistant to other drugs[65,66]. TLM inhibits KasA and KasB, two enzyme components of the specialized FAS II system involved in the synthesis of the very long-chain meromycolic acids, constituent of building blocks for bacterial cell walls[67,68].

The physical and pharmacokinetic properties of TLM, such as low molecular weight (MW 210 $\mathrm{g} / \mathrm{mol})$, high water solubility, appropriate lipophilicity $(\log \mathrm{P}=3)$, good oral absorption, and low toxicity profile in mice[69] made it an attractive lead molecule for TB treatment[70]. The success of TLM has increased the efforts towards the synthesis of even more effective agents, leading to the current list of compounds that present a good level of activity and can be seen as promising drugs in curing TB disease. 


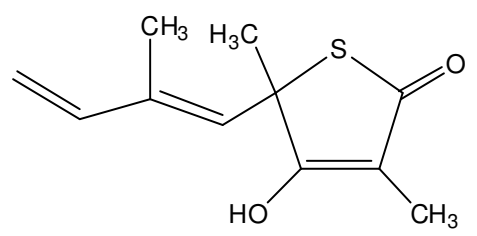

Thiolactomycin

FIGURE 14. Structure of thiolactomycin (TLM).

The most common synthetic route for the synthesis of thiolactone ring is described by Wang and Salvino (Scheme 25)[71]. This method involves Claisen self-ester condensation of methyl propionate 132 to generate $\beta$-keto ester 133. Selective bromination of 133 , followed by nucleophilic substitution of bromine by thioacetic acid gave thioester 135. Finally, cyclization in basic conditions furnished the thiolactone 136, the key intermediate for the synthetic approach to thiolactomycin analogues.

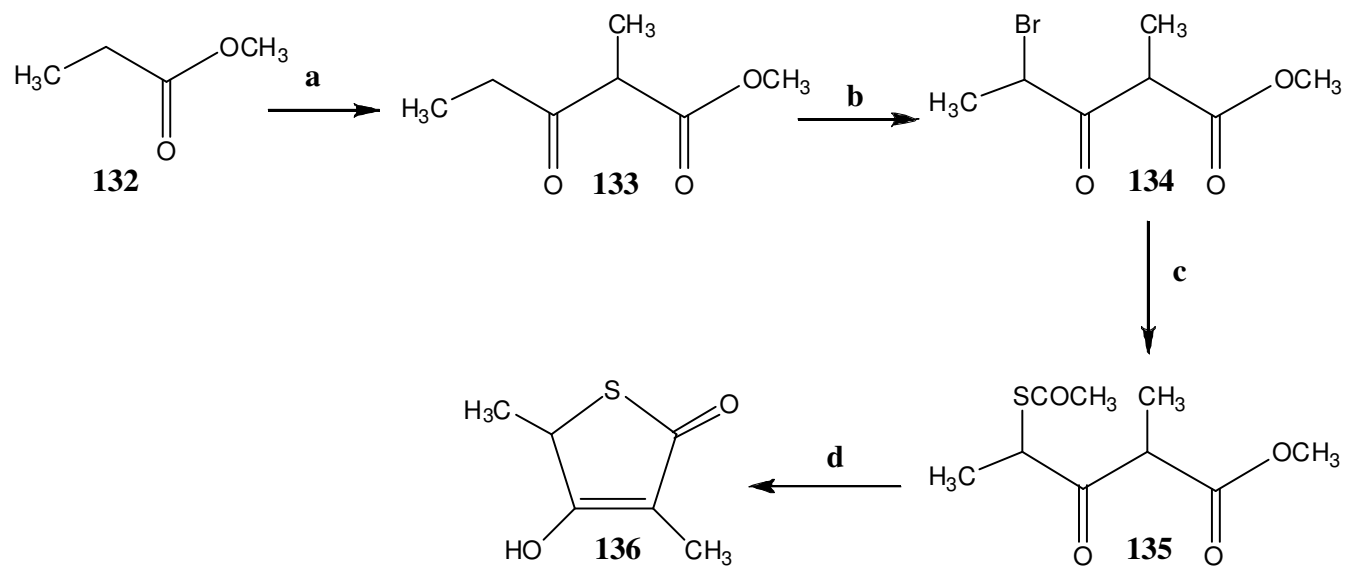

SCHEME 25. Synthesis of thiolactone 136. (a) Anhydrous KH, THF; (b) $\mathrm{PyHBr}_{3}$, acetic acid; (c) $\mathrm{AcSH}_{2} \mathrm{Et}_{3} \mathrm{~N}$, $\mathrm{CH}_{2} \mathrm{Cl}_{2} ;$ d) $\mathrm{KOH}, \mathrm{H}_{2} \mathrm{O}-\mathrm{EtOH}$.

Recently, Senior and coworkers[72] described the preparation of a series of TLM analogues (Scheme 26). The synthesis was based on the introduction of propargyl group in the C-5 position of the thiolactone 136, followed by Sonogashira coupling reaction, producing compounds 138a-c in 47-86\% yields. These compounds exhibit higher in vitro inhibitory activity against the recombinant $M$. $t b$. B-ketoacyl-ACP synthase mtFabH condensing enzyme (Table 7) when compared to TLM.

Kamal and coworkers synthesized (Scheme 27) and evaluated (Table 8) the anti-TB activity of a series of thiolactomycin analogues[73]. Preliminary studies have demonstrated that analogues 140 and 141 displayed moderate activities against $M . t b . \mathrm{H}_{37} \mathrm{Rv}$ and clinical isolates (sensitive strains), however, significant activity against MDR strains. These thiolactomycin analogues have been synthesized from thiolactone 136 by the etherification of hydroxy group with alkyl dihalides to afford compounds 139 and 140. The bromo ether derivative 140 was treated with methylthioglycolate to produce compound 141.

Starting from the crystal structure of $M$. $t b$. antigen $85 \mathrm{C}$, Gobec and coworkers[74] designed and synthesized a series of phosphonate inhibitors of its mycolyltransferase activity. The inhibitors, comprised of a phosphonate moiety, mycolic acid mimetic, and a trehalose surrogate, were tested for their inhibition of recombinant $M$. $t b$. antigen $85 \mathrm{C}$ mycolyltransferase activity and for in vitro $M$. avium growth inhibition assay. Ethyl 3-phenoxybenzyl butylphosphonate 142 and (1,3-dioxo-1,3-dihydro-2H-isoindol2-yl) methyl ethyl heptylphosphonate 143 inhibited the mycolyltransferase activity of antigen $85 \mathrm{C}$ with 


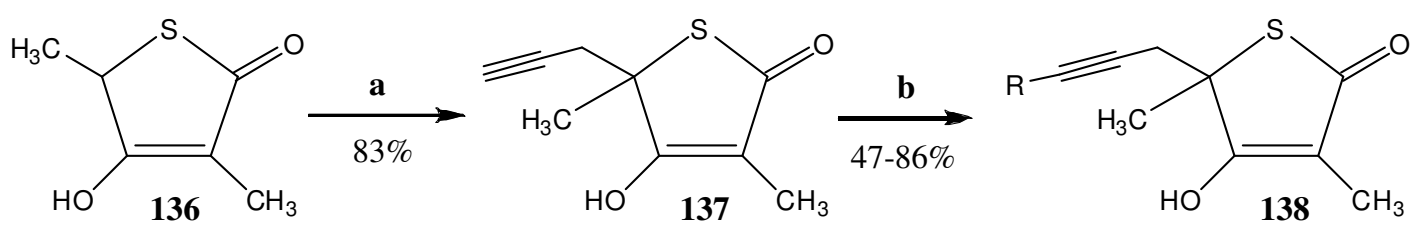

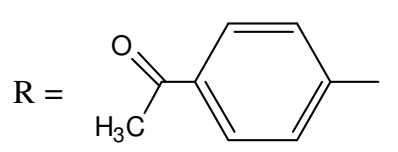

a

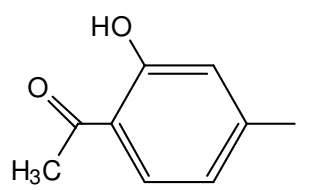

b

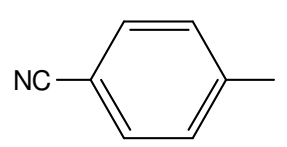

c

SCHEME 26. Synthesis of thiolactone 138. (a) LHMDS, $\mathrm{HCCCH}_{2} \mathrm{Br},-78^{\circ} \mathrm{C}$; (b) DMF, $\mathrm{Et}_{3} \mathrm{~N}, \mathrm{CuI},\left(\mathrm{PPh}_{3}\right)_{2} \mathrm{PdCl}, \mathrm{R}-\mathrm{I}$.

TABLE 7

In vitro mtFabH Activity

\begin{tabular}{lc}
\hline Compounds & $\mathbf{I C}_{\mathbf{5 0}}, \boldsymbol{\mu} \boldsymbol{M}$ ( $\left.\mathbf{m t F a b H}\right)$ \\
\hline TLM & 74.9 \\
138a & $4 \pm 0.4$ \\
138b & $7 \pm 0.2$ \\
138c & $7 \pm 0.5$ \\
\hline
\end{tabular}

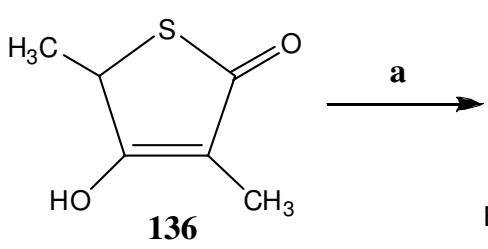

SCHEME 27. Synthesis of thiolactone 141 anhydrous $\mathrm{K}_{2} \mathrm{CO}_{3}$, acetone, reflux.

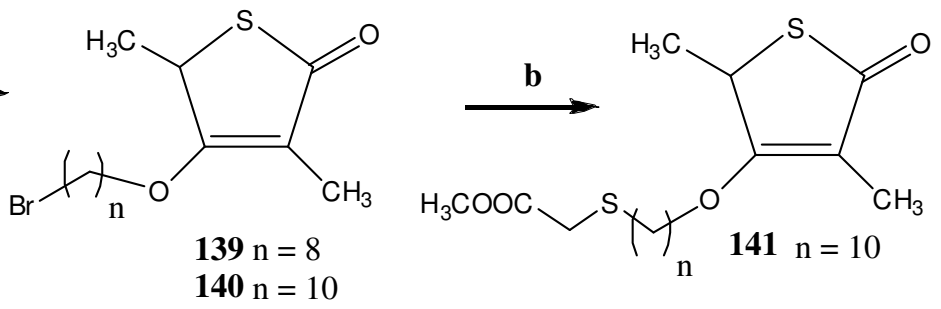

. (a) $\mathrm{Br}\left(\mathrm{CH}_{2}\right)_{\mathrm{n}} \mathrm{Br}$, anhydrous $\mathrm{K}_{2} \mathrm{CO}_{3}$, acetone, reflux; (b) $\mathrm{CH}_{3} \mathrm{OOCCH}_{2} \mathrm{SH}$,

\section{TABLE 8}

MIC Values $(\mu \mathrm{g} / \mathrm{ml})$ of Compounds 140 and 141 and Isoniazid

\begin{tabular}{lccc}
\hline Compound & $\begin{array}{c}\text { M.tb. } \\
\mathbf{H}_{37} \mathbf{R v}\end{array}$ & $\begin{array}{c}\text { M. tb. } \\
\text { Clinically } \\
\text { Sensitive }\end{array}$ & $\begin{array}{c}\text { M. tb. } \\
\text { MDR }\end{array}$ \\
\hline 140 & 4.0 & $4.0-16.0$ & $4.0-16.0$ \\
141 & 1.0 & $1.0-4.0$ & $1.0-4.0$ \\
Isoniazid & 0.25 & $0.12-0.25$ & $8->16$ \\
\hline
\end{tabular}


$\mathrm{IC}_{50}$ in the low micromolar range. Compound $\mathbf{1 4 2}$ proved to be the most promising compound, inhibiting the antigen $85 \mathrm{C}$ with an $\mathrm{IC}_{50}$ value of $2.0 \mu M$ and showing substantial in vitro inhibition of growth of $M$. avium. Whereas compound 143 was the most potent inhibitor of mycolyltransferase activity $\left(\mathrm{IC}_{50}=1.3\right.$ $\mu M$ ), it showed no detectable activity against M. avium in the in vitro assay (Fig. 15) .

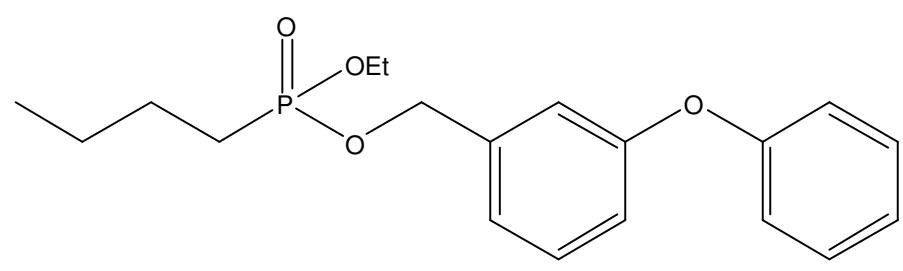

142

$\mathrm{IC}_{50}=2.0 \mu \mathrm{M} ; \mathrm{MIC}=248.8 \pm 129.8 \mu \mathrm{g} / \mathrm{ml}$

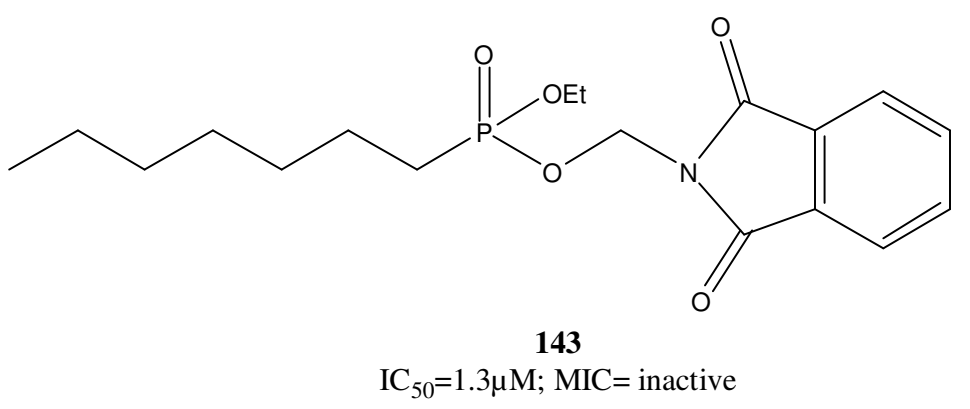

FIGURE 15. Structures of compounds 142 and 143.

\section{CONCLUSION}

Because TB has become a worldwide problem again, there is an urgent need for new drugs and strategies to fight against this important infectious disease. In this context, the mycobacterial cell wall regains attention, and due to modern analysis techniques and the elucidation of the $M$. $t b$. Genome, there is now a better comprehension of the different aspects of the cell wall of $M$. $t b$., such as structure, biosynthesis, and genetics aspects. Considering the latter and the importance of mycolic acids for maintenance of the integrity of the mycobacterial cell wall, this class of compounds has become an attractive cellular target for the development of novel drugs against TB.

\section{ABBREVIATIONS}

$\mathbf{A c}=$ Acetyl $; \mathbf{A c c D}_{\mathbf{4}} / \mathbf{A c c D}_{\mathbf{5}}=$ Acyl-CoA carboxylases 4 and $5 ; \mathbf{A C P}=$ Acyl carrier protein; $\mathbf{A G}=$ Arabinogalactan; AG-M = Arabinogalactan-mycolate; Ag85 = Antigen 85; AIDS = Acquired immune deficiency syndrome; AMP = Adenosine monophosphate; $\mathbf{B C G}=$ Bacillus Calmette-Guérin; $\boldsymbol{n}$-Bu $=n$ buthyl; $\mathbf{D E}=\beta$-hydroxyacyl dehydrase; $\mathbf{D E A D}=$ Diethyl azodicarboxylate; $(\mathbf{D H Q D})_{2} \mathbf{P H A L}=$ Hydroquinidine 1,4-phthalazinediyl diether; DMAP $=$ 4-Dimethylaminopyridine; DMF $=N, N$ Dimethylformamide; DMSO = Dimethyl sulfoxide; DA = Arabinofuranosyl residue; DPA $=\beta$-Darabinofuranosyl-1-monophosphoryldecaprenol; $\mathbf{E R}=$ Enoyl reductase; $\mathbf{E T H}=$ Ethionamide; $\mathbf{E T M}=$ Ethambutol; Et = Ethyl; FAS-I = Fatty acid synthase type I; FAS-II = Fatty acid synthase type II; HMDS $=$ Hexamethyldisilazane; HMPA = Hexamethylphosphoramide; $\mathbf{I C}_{\mathbf{5 0}}=$ Half maximal inhibitory; $\mathbf{I M S}=$ 
Methylated spirits ("metho") is a mixture of ethyl alcohol (95\%) and methyl alcohol (\%5); INH = Isoniazid; KAS = $\beta$-ketoacyl synthase; $\mathbf{K R}=\beta$-ketoacyl reductase; $\mathbf{L D A}=$ Lithium di-isopropylamide; LiBSA = Lithium $N, O$-Bis(trimethylsilyl)acetamide; $\mathbf{m A G P}=$ Mycolyl-arabinogalactan-peptidoglycan; MCPBA $=m$-Chloroperoxybenzoic acid; $\mathbf{M D R}=$ Multidrug resistant; $\mathbf{M e}=$ Methyl; $\mathbf{M I C}=$ Minimum inhibitory concentration; $\mathbf{M S}=$ Mass spectrometry; MST $=$ Mean survival time; $\boldsymbol{M} . \mathbf{t} \boldsymbol{b} .=$ Mycobacterium tuberculosis; $\quad$ Myc-PL = 6-O-mycolyl- $\beta$-D-mannopyranosyl-1-phosphoheptaprenol; $\quad \mathbf{N A D}^{+}=$ Nicotinamide adenine dinucleotide; NADH $=$ Reduced form of NAD+; NADPH $=$ Nicotinamide adenine dinucleotide phosphate; NBS $=N$-Bromosuccinimide; NMR $=$ Nuclear magnetic resonance; Pks $\mathbf{1 3}=$ Polyketide synthase 13; $\mathbf{P C C}=$ Pyridinium chlorochromate; $\mathbf{P h}=$ Phenyl $\mathbf{P v}=$ Pivaloyl $\mathbf{P y}=$ Pyridine; SAM = S-Adenosyl-L-methionine; $\mathbf{T B}=$ Tuberculosis; $\mathbf{T B A B}=$ Tetra $n$-butyl ammonium bromide; TBAF = Tetra $n$-butyl ammonium fluoride; TBDMSCI $=t$-Butyldimethylsilyl chloride; $\mathbf{T D M}=$ Trehalose dimycolate; $\mathbf{T M L}=$ Thiolactomycin; $\mathbf{T M M}=$ Trehalose monomycolate; $\mathbf{T H F}=$ Tetrahydrofuran; Ts = Tosyl.

\section{REFERENCES}

1. $\quad$ Brennan, P.J. and Nikaido, H. (1995) Annu. Rev. Biochem. 69, $29-63$.

2. (a) Barry, C.E., III, Lee, R.E., Mdluli, K., Sampson, A.E., Schoeder, B.G., Slayden, R.A., and Yuan, Y. (1998) Prog. Lipids Res. 37, 143-179; (b) Brennan, P.J. (2003) Tuberculosis 83, 9197.

3. Heath, R.J., White, S.W., and Rock, C.O. (2002) Appl. Microbiol. Biotechnol. 58, 695-703.

4. (a) Minnikin, D.E. (1982) In The Biology of the Mycobacteria. Ratledge, C. and Stansford, J., Eds. Academic Press, London. pp. 95-184; (b) Asselineau, C., Asselineau, J., Lanéelle, G., and Lanéelle, M.A. (2002) Prog. Lipid Res. 41, 501-523.

5. (a) Stodola, F.H., Lesuk, A., and Anderson, R.J. (1938) J. Biol. Chem. 126, 505-513; (b) Anderson, R.J. (1941) Chem. Rev. 29, 225-243; (c) Anderson, R.J. (1939) Fortschr. Chem. Org. Naturst. 3, 145.

6. (a) Asselineau, J. (1950) C. R. Acad. Sci. 230, 1620; (b) Asselineau, J. and Lederer, E. (1950) Nature 166, $782-793$.

7. (a) Souza, M.V.N. (2005) Mini-Rev. Med. Chem. 5, 1009-1018; (b) Souza, M.V.N. and Vasconcelos, T.A. (2005) Quím. Nova 28, 678-682; (c) Souza, M.V.N. (2005) TheScientificWorldJOURNAL 5, 609-628; (d) Souza, M.V.N. (2006) Curr. Op. Pulmon. Med. 12, 167-171; (e) Souza, M.V.N., Vasconcelos, T.A., Cardoso, S.H., and Almeida, M.V. (2006) Curr. Med. Chem. 13, 455-463; (f) Souza, M.V.N. (2006) TheScientificWorldJOURNAL 6, 847-861.

8. Campbell, J.W. and Cronan, J.E., Jr. (2001) Bacterial fatty acid biosynthesis: targets for antibacterial drug discovery. Annu. Rev. Microbiol. 55, 305-332.

9. Asselineau, J. and Lanéelle, G. (1998) Mycobacterial lipids: a historical perspective. Front. Biosci. 3, 164.

10. Takayama, K., Wang, C., and Besra, G.S. (2005) Pathway to synthesis and processing of mycolic acids in Mycobacterium tuberculosis. Clin. Microbiol. Rev. 18, 81-101.

11. Schaeffer, M.L., Agnihotri, G., Volker, C., Kallender, H., Brennan, P.J., and Lonsdale, J.T. (2001) Purification and biochemical characterization of the Mycobacterium tuberculosis $\beta$-ketoacyl-acyl carrier protein synthases KasA and KasB. J. Biol. Chem. 276, 47029-47037.

12. Gao, L.Y., Laval, F., Lawson, E.H., Groger, R.K., Woodruff, A., Morisaki, J.H., Cox, J.S., Daffe, M., and Brown, E.J. (2003) Requirement for kasB in Mycobacterium mycolic acid biosynthesis, cell wall impermeability and intracellular survival: implications for therapy. J. Mol. Microbiol. 49, 1547-1563.

13. Kremer, L., Dover, L.G., Carrère, S., Nampoothiri, K.M., Lesjean, S., Brown, A.K., Brennan, P.J., Minnikin, D.E., Locht, C., and Besra, G.S. (2002) Mycolic acid biosynthesis and enzymic characterization of the beta-ketoacyl-ACP synthase A-condensing enzyme from Mycobacterium tuberculosis. Biochem. J. 364, 423-430.

14. Bannerjee, A.E., Dubnau, A., Quemard, V., Balasubramanian, K.S., Ulm, T., Wilson, D., Collins, G., DeLisle, W., and Jacobs, R., Jr. (1994) inhA, a gene encoding a target for isoniazid and ethionamide in Mycobacterium tuberculosis. Science 263, 227-230.

15. Midluli, K., Slayden, R.A., Zhu, Y.Q., Ramaswamy, S., Pan, X., Mead, D., Crane, D.D., Musser, J.M., and Barry, C.E. (1998) Inhibition of a Mycobacterium tuberculosis $\beta$-ketoacyl ACP synthase by isoniazid. Science 280, 16071610.

16. Dinadayala, P., Laval, F., Raynaud, C., Lemassu, A., Laneelle, M.A., Laneelle, G., and Daffe, M. (2003) Tracking the putative biosynthetic precursors of oxygenated mycolates of Mycobacterium tuberculosis. Structural analysis of fatty acids of a mutant strain devoid of methoxy- and ketomycolates. J. Biol. Chem. 278, 7310-7319.

17. Yuan, Y., Crane, D.C., Musser, J.M., Sreevatsan, S., and Barry, C.E. (1997) MMAS-1, the branch point between cisand trans-cyclopropane-containing oxygenated mycolates in Mycobacterium tuberculosis. J. Biol. Chem. 272, 1004110049 .

18. Glickman, M.S., Cahill, S.M., and Jacobs, W.R., Jr. (2001) The Mycobacterium tuberculosis cmaA2 gene encodes a 
mycolic acid trans-cyclopropane synthetase. J. Biol. Chem. 276, 2228-2233.

19. George, K.M., Yuan, Y., Sherman, D.R., and Barry, C.E. (1995) The biosynthesis of cyclopropanated mycolic acids in Mycobacterium tuberculosis. J. Biol. Chem. 270, 27292-27298.

20. Glickman, M. S. (2003) The mmaA2 gene of Mycobacterium tuberculosis encodes the distal cyclopropane synthase of the $\alpha$-mycolic acid. J. Biol. Chem. 278, 7844-7849.

21. Barry, C.E., Lee, R.E., Mdluli, K., Sampson, A.E., Schroeder, B.G., Slayden, R.A., and Yan, Y. (1995) Identification of a gene involved in the biosynthesis of cyclopropanated mycolic acids in Mycobacterium tuberculosis. Proc. Natl. Acad. Sci. U. S. A. 92, 6630-6634.

Portevin, D., Sousa-D'Auria, C., Houssin, C., Grimaldi, C., Chami, M., Daffé, M., and Guilhot, C. (2004) A polyketide synthase catalyzes the last condensation step of mycolic acid biosynthesis in mycobacteria and related organisms. Proc. Natl. Acad. Sci. U. S. A. 101, 314-319.

23. Jackson, M., Raynaud, C., Laneelle, M.A., Guilhot, C., Laurent-Winter, C., Ensergueix, D., Gicquel, B., and Daffe, M. (1999) Inactivation of the antigen $85 \mathrm{C}$ gene profoundly affects the mycolate content and alters the permeability of the Mycobacterium tuberculosis cell envelope. Mol. Microbiol. 31, 1573-1587.

24. Kremer, L., Maughan, W.N., Wilson, R.A., Dover L.G., and Besra G.S. (2002) The M. tuberculosis antigen 85 complex and mycolyltransferase activity. Lett. Appl. Microbiol. 34, 233-237.

Puech, V., Bayan, N., Salim, K., Leblon, G., and Daffe, M. (2000) Characterization of the in vivo acceptors of the mycoloyl residues transferred by the corynebacterial PS1 and the related mycobacterial antigens 85 . Mol. Microbiol. 35, 1026-1041.

Crick, D.C., Mahapatra, S., and Brennan, P.J. (2001) Biosynthesis of the arabinogalactan-peptidoglycan complex of Mycobacterium tuberculosis. Glycobiology 11, 107R-118R.

27. Content, J., Cuvellerie, A., Wit, L., Vicent-Levy-Frebault, V., Ooms, J., and Bruyn, J. (1991) The genes coding for the antigen 85 complexes of Mycobacterium tuberculosis and Mycobacterium bovis BCG are members of a gene family: cloning, sequence determination, and genomic organization of the gene coding for antigen 85-C of $\mathrm{M}$. tuberculosis. Infect. Immun. 59, 3205-3212.

28. Middlebrook, G. (1952) Sterilization of tubercle bacilli by isonicotinic acid hydrazid and the incidence of variants resistant to the drug in vitro. Am. Rev. Tuberc. 65, 765-767.

29. Marrakchi, H., Laneelle, G., and Quemard, A. (2000) InhA, a target of the antituberculous drug isoniazid, is involved in a mycobacterial fatty acid elongation system, FAS-II. Microbiology 46, 289-296.

30. Rouse, D.A. and Morris, S.J. (1995) Molecular mechanisms of isoniazid resistance in Mycobacterium tuberculosis and Mycobacterium bovis. Infect. Immun. 63, 1427.

Marttila, H.J., Soini, H., Huovinen, P., and Viljanen, M.K. (1996) Antimicrob. Agents Chemother. 40, 2187.

Rawat, R., Whitty, A., and Tonge, P.J. (2003) Proc. Natl. Acad. Sci. U. S. A. 100, 13881.

Vilchèze, C., Weisbrod, T.R., Chen, B., Kremer, L., Hazbón, M.H., Wang, F., Alland, D., Sacchettini, J.C., and Jacobs, W.R., Jr. (2005) Antimicrob. Agents Chemother. 49, 708.

34. Lei, B., Wei, C., and Tu, S. (2000) J. Biol. Chem. 275, 2520.

35. Vannelli, T.A., Dykman, A., and Montellano, P.R.O. (2002) J. Biol. Chem. 277, 12824.

36.

37. Baulard, A.R., Betts, J.C., Engohang-Ndong, J., Quan, S., McAdam, R.A., Brennan, P.J., Locht, C., and Besra, G.S. 9677 (2000) J. Biol. Chem. 275, 28326.

38. Wang, F., Langley, R., Gulten, G., Dover, L.G., Besra, G.S., Jacobs, W.R., Jr., and Sacchettini, J.C. (2007) J. Exp. Med. 204, 73.

39. Deng, L., Mikusova, K., Robuck, K.G., Scherman, M., Brennan P.J., and McNeil, M.R. (1995) Antimicrob. Agents Chemother. 39, 694.

40. Takayama, K. and Kilburn, J.O. (1989) Antimicrob. Agents Chemother. 33, 1493.

41. Alderwick, L.J., Seidel, M., Sahm, H., Besra, G.S., and Eggeling, L. (2006) J. Biol. Chem. $281,15653$.

42.

Mikuš̃ová, K., Huang, H., Yagi, T., Holsters, M., Vereecke, D., D'Haeze, W., Scherman, M.S., Brennan, P.J., McNeil, M.R., and Crick, D.C. (2005) J. Bacteriol. 187, 8020.

43. Belanger, A.E., Besra, G.S., Ford, M.E., Mikušová, K., Belisle, J.T., Brennan, P.J., and Inamine, J.M. (1996) Proc. Natl. Acad. Sci. U. S. A. 93, 11919.

44.

Escuyer, V.E., Lety, M., Torrelles, J.B., Khoo, K., Tang, J., Rithner, C.D., Frehel, C., McNeil, M.R., Brennan, P.J., and Chatterjee, D. (2001) J. Biol. Chem. 276, 48854.

(1999) Tetrahedron Lett. 40, 6689.

46. Coxon, G.D., Douglas, J.D., and Minnikin, D.E. (2003) Chem. Phys. Lipids 126, 9.

47. Coxon, G.D., Al Dulayymi, J.R., Morehouse, C., Brennan, P.J., Besra, G.S., Baird, M.S., David, E., and Minnikin, D.E. (2004) Chem. Phys. Lipids 127, 35. 
Souza, M.V.N., Neves Junior, I., Miranda, G.B.P., Lourenço, M.C.S., Vasconcelos, T.A., Pais, K.C., Wardell, J.L., Wardell, S.M.S.V., and Alcantara Junior, J.P. (2006) Lett. Drug Des. Discov. 3, 424; (c) Souza, M.V.N., Wardell, S.M.S.V., Ferreira, M.L., Wardell, J.L., Vasconcelos, T.A., Mascarenhas, Y.P., Ellena, J., and Silva, F.P., Jr. (2006) J. Mol. Struct. 788, 63; (d) Souza, M.V.N., Wardell, J.L., Wardell, S.M.S.V., Vasconcelos, T.A., Low, J.N., and Glidewell, C. (2006) Acta Cryst. C62, 0618; (e) Souza, M.V.N., Vasconcelos, T.A., Mello, S.C.P., Wardell, S.M.S.V., Peralta, M.A., Ferreira, B., Henrique, M.G.M.O., Neves Junior, I., and Lourenço, M.C.S. (2005) Lett. Drug Des. Discov. 2, 451; (f) Hearn, M.J. and Cynamon, M.H. (2004) J. Antimicrob. Chemother. 53, 185; (g) Maccari, R., Ottanà, R., Monforte, F., and Vigorita, M.G. (2002) Antimicrob. Agents Chemother. 46, 294.

52. Silma, N., Jain, S., Tilekar, A., Upadhayaya, R.S., Kishore, N., Jana, G.H., and Arora, S.K. (2005) Bioorg. Med. Chem. Lett. 15, 1573.

53. (a) Phetsuksiri, B., Baulard, A.R., Cooper, A.M., Minnikin, D.E., Douglas, J.D., Besra, G.S., and Brennan, P.J. (1999) Antimicrob. Agents Chemother. 43, 1042; (b) Phetsuksiri, B., Jackson, M., Scherman, H., McNeil, M., Besra, G.S., Baulard, A.R., Slayden, R.A., Debarber, A.E., Barry, C.E., Baird, M.S., Crick, D.C., and Brennan, P.J. (2003) J. Biol. Chem. 278, 53123.

54. Bhowruth, V., Brown, A.K., Reynolds, R.C., Coxon, G.D., Mackay, S.P., Minnikin, D.E., and Besra, G.S. (2006) Bioorg. Med. Chem. Lett. 16, 4743.

55. Protopopova, M., Hanrahan, C., Nikonenko, B., Samala, R., Chen, P., Gearhart, J., Einck, L., and Nacy, C.A. (2005) J. Antimicrob. Chemother. 56, 968.

56. Razafimahefa, D., Ralambomanana, D.A., Hammouche, L., Pélinski, L., Lauvagie, S., Bebear, C., Brocard, J., and Maugein, J. (2005) Bioorg. Med. Chem. Lett. 15, 2301.

57. (a) Tewari, N., Tiwari, V.K., Tripathi, R.P., Chaturvedi, V., Srivastava, A., Srivastava, R., Shukla, P.K., Chatuverdi, A.K., Gaikwad, A., Sinha, S., and Srivastava, B.S. (2004) Bioorg. Med. Chem. Lett. 14, 329; (b) Tripathi, R.P., Tiwari, V.K., Tewari, N., Katiyar, D., Saxena, N., Sinha, S., Gaikwad, A., Srivastava, A., Chaturvedi, V., Manju, Y.K., Srivastava, R., and Srivastava, B.S. (2005) Bioorg. Med. Chem. Lett. 13, 5668.

58. Katiyar, D., Tiwari, V.K., Tewari, N., Verma, S.S., Sinha, S., Gaikwad, A., Srivastava, A., Chaturvedi, V., Srivastava, R., Svristava, B.S., and Tripathi, R.P. (2005) Eur. J. Med. Chem. 40, 351.

59. Dwivedi, N., Tewari, N., Tiwari, V.K., Chaturvedi, V., Manju, Y.K., Srivastava, A., Giakwad, A., Sinha, S., and Tripathi, R.P. (2005) Bioorg. Med. Chem. Lett. 15, 4526.

60. Stover C.K., Warrener, P., VanDevanter, D.R., Sherman, D.R., Arain, T.M, Langhorna, M.H., Anderson, S.W., Towell, J.A., Yuan, Y., McMurray, D.N., Kreiswirth, B.N., Barry, C.E., and Baker, W.R. (2000) Nature 405, 962.

61. Tangallapall, R.P., Yendapally, R., Lee, R.E., Hevener, K., Jones, V.C., Lenaerts, A.J.M., McNeil, M.R., Wang, Y., Franzblau, S., and Lee, R.E. (2004) J. Med. Chem. 47, 5276.

62. Pan, F., Jackson, M., Ma, Y., and McNeil, M. R. (2001) J. Bacteriol. 183, 3991.

63. Scherman, M.S., Winans, K., Bertozzi, C.R., Stern, R., Jones, V.C., and McNeil, M.R. (2003) Antimicrob. Agents Chemother. 47, 378-382.

64. Oishi, H., Noto, T., Sasaki, H., Suzuki, K., Hayashi, T., Okazaki, H., Ando, K., and Sawada, M. (1982) J. Antibiot. 35, 391.

65. Noto, T., Miyakawa, S., Oishi, H., Endo, H., and Okazaki, H. (1982) J. Antibiot. 35, 401.

66. Kremer, L., Douglas, J.D., Baulard, A.R., Morehouse, C., Guy, M.R., Alland, D., Dover, L.G., Lakey, J.H., Jacobs, W.R., Brennan, P.J., Minnikin, D.E., and Besra, G.S. (2000) J. Biol. Chem. 275, 16857.

67. Slayden, R.A., Lee, R.E., Armour, J.W., Cooper, A.M., and Orme, I. M. (1996) Antimicrob. Agents Chemother. 40, 2813.

68. Nishida, I., Kawaguchi, A., and Yamada, M. (1986) J. Biochem. 99, 1447.

69. Miyakawa, S., Suzuki, K., Noto, T., Harada, Y., and Okazaki, H. (1982) J. Antibiot. 35, 411.

70. Lipinski, C.A., Lombardo, F., Dominy, B.W., and Feeney, P.J. (2001) Adv. Drug Deliv. Rev. $46,3$.

71. Wang, C.L.J. and Salvino, J.M. (1984) Tetrahedron Lett. 25, 5243.

72. Senior, S.J., Illarionov, P.A., Gurcha, S.S., Campbell, I.B., Schaeffer, M.L., Minnikin, D.E., and Besra, G.S. (2004) Bioorg. Med. Chem. Lett. 14, 373.

73. Kamal, A., Shaik, A.A., Sinha, R., Yadav, J.S., Arora, S.K. (2005) Bioorg. Med. Chem. Lett. $15,1927$.

74. Gobec, S., Plantan, I., Mravljak, J., Švajger, U., Wilson, R.A., Besra, G.S., Soares, S.L., Appelberg, R., Kikelj, D. (2007) Eur. J. Med. Chem. 42, 54.

\section{This article should be cited as follows:}

Souza, M.V.N., Ferreira, M.L., Pinheiro, A.C., Saraiva, M.F., Almeida, M.V., and Valle, M.S. (2008) Synthesis and biological aspects of mycolic acids: an important target against Mycobacterium tuberculosis. TheScientificWorldJOURNAL 8, 720-751. DOI 10.1100/tsw.2008.99. 

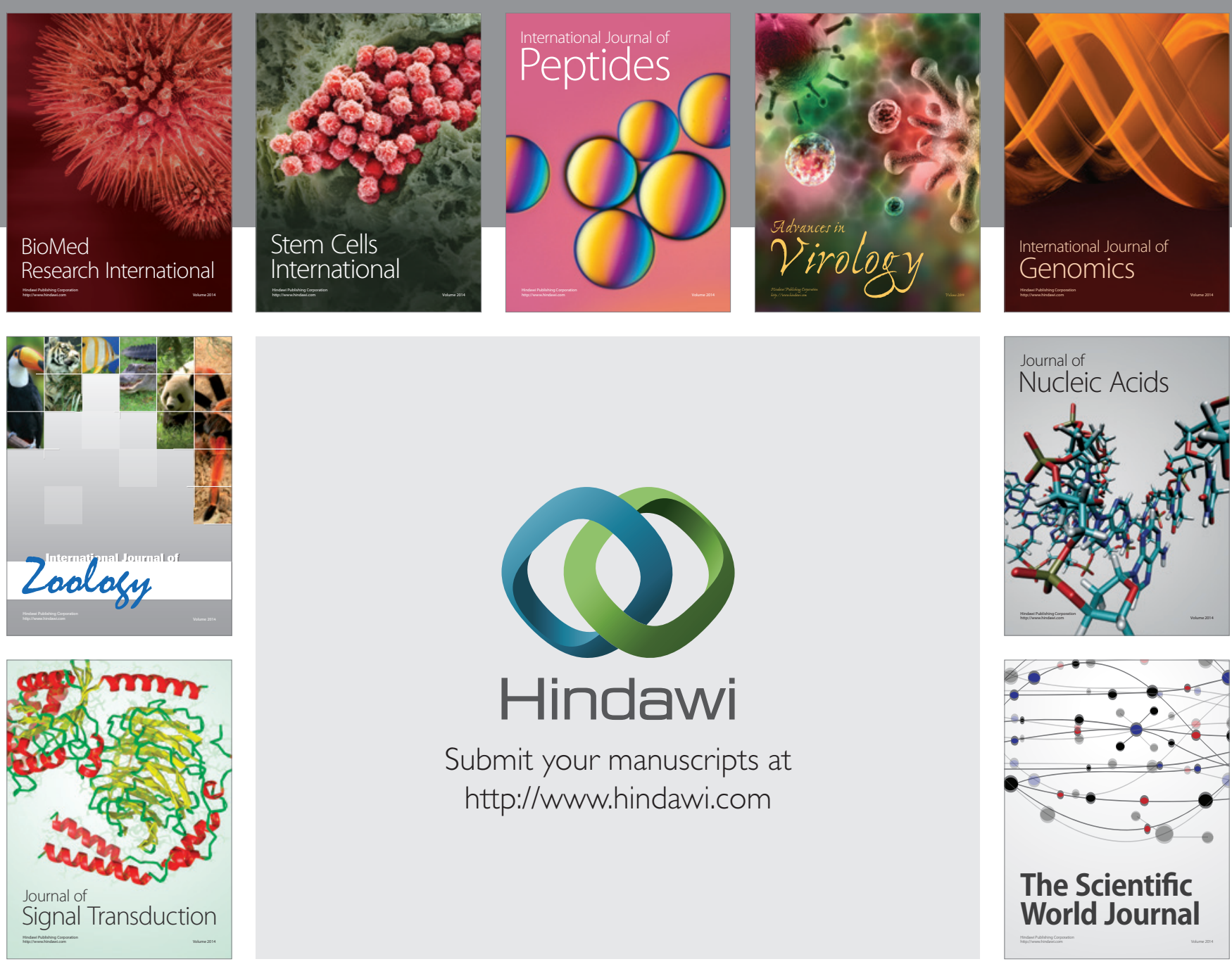

Submit your manuscripts at

http://www.hindawi.com
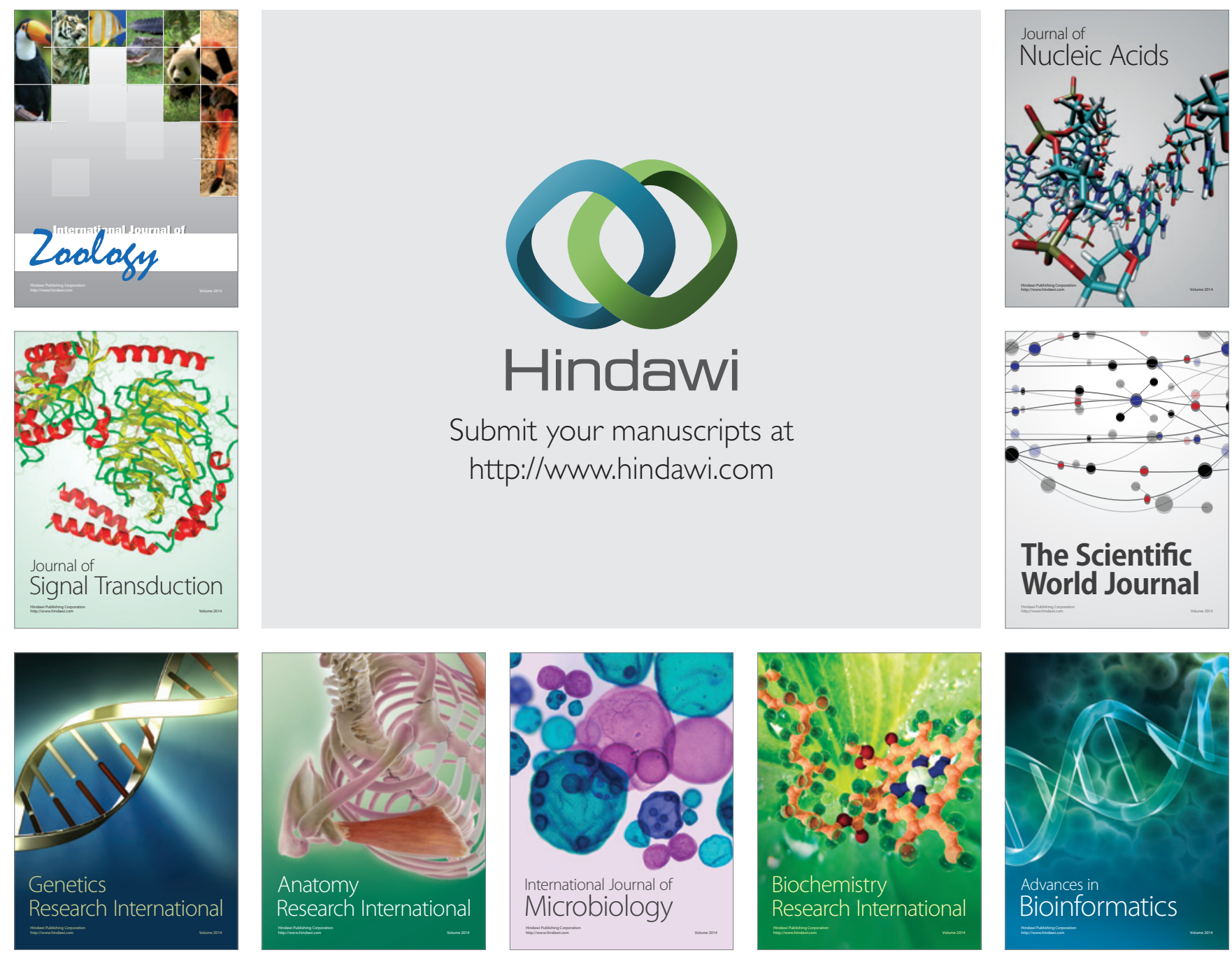

The Scientific World Journal
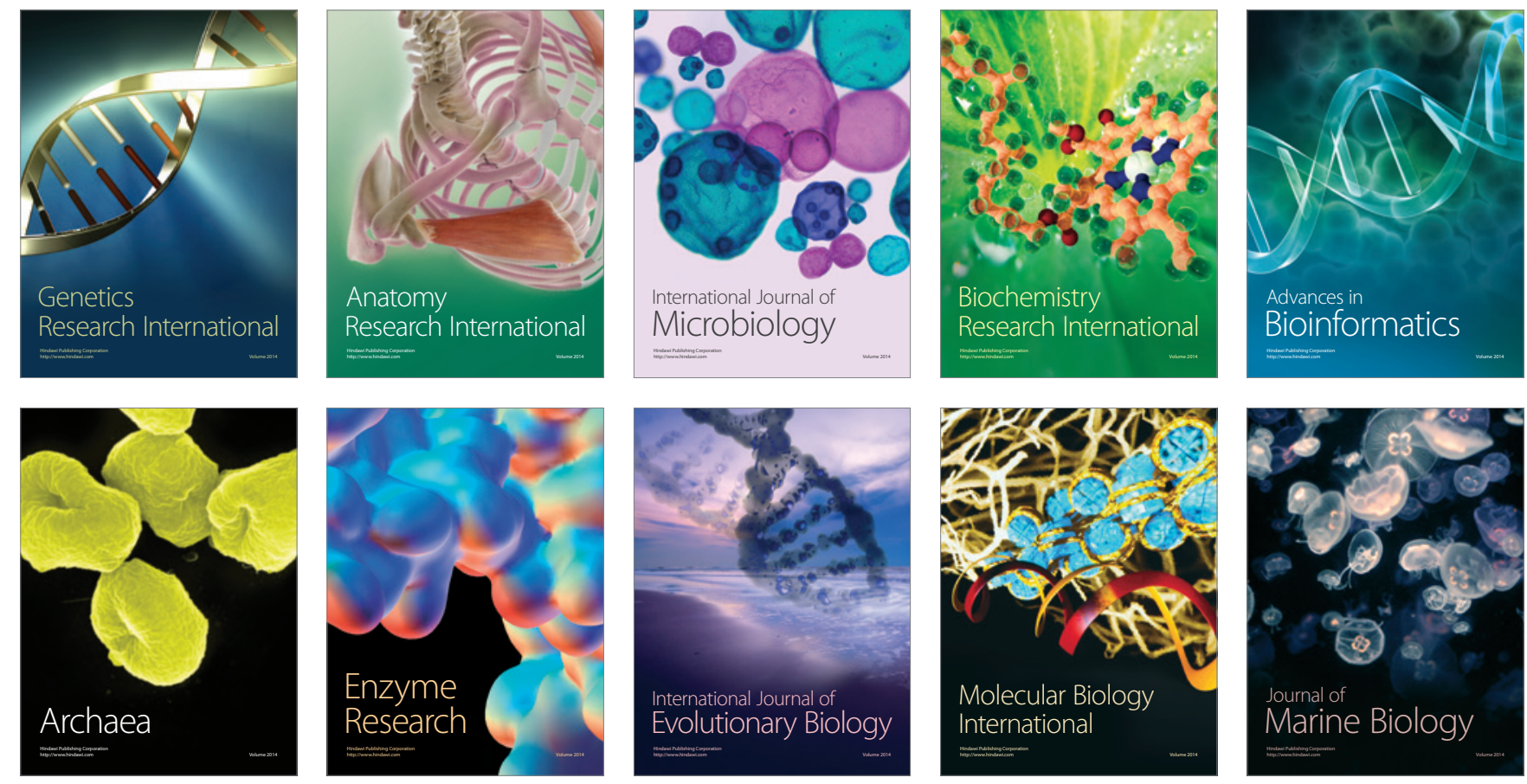